\title{
Preliminary results of models to predict areas in the Americas with increased likelihood of Zika virus transmission in 2017
}

The ZIKAVAT Collaboration*

*Zika Modeling and Projections for Vaccination Trials Collaboration (in alphabetical order): Jason Asher ${ }^{1}$, Christopher Barker ${ }^{2}$, Grace Chen ${ }^{3}$, Derek Cummings ${ }^{4,5}$, Matteo Chinazzi ${ }^{6}$, Shelby Daniel-Wayman $^{3}$, Marc Fischer ${ }^{7}$, Neil Ferguson ${ }^{8}$, Dean Follman ${ }^{3}$, M. Elizabeth Halloran ${ }^{9,10}$, Michael Johansson ${ }^{7}$, Kiersten Kugeler ${ }^{7}$, Jennifer Kwan ${ }^{3}$, Justin Lessler ${ }^{4}$, Ira M. Longini ${ }^{5}$, Stefano Merler $^{11}$, Andrew Monaghan ${ }^{12}$, Ana Pastore y Piontti ${ }^{6}$, Alex Perkins ${ }^{13}$, D. Rebecca Prevots ${ }^{3}$, Robert Reiner $^{10}$, Luca Rossi ${ }^{14}$, Isabel Rodriguez-Barraquer ${ }^{4,15}$, Amir S. Siraj ${ }^{13}$, Kaiyuan Sun ${ }^{6}$, Alessandro Vespignani ${ }^{6}$, Qian Zhang ${ }^{6}$.

${ }^{1}$ Biomedical Advanced Research and Development Authority, Washington, DC, USA;

${ }^{2}$ University of California, Davis, California, USA; ${ }^{3}$ National Institutes of Health, Bethesda, MD, USA; ${ }^{4}$ Johns Hopkins, Bloomberg School of Public Health, Baltimore, Maryland, USA; ${ }^{5}$ University of Florida, Gainesville, Florida, USA; ${ }^{6}$ Northeastern University, Boston, Massachusetts, USA; ${ }^{7}$ Centers for Disease Control and Prevention, Fort Collins, Colorado and San Juan, Puerto Rico, USA; ${ }^{8}$ Imperial College, London, UK; ${ }^{9}$ Fred Hutchinson Center, Seattle, WA, USA; ${ }^{10}$ University of Washington, Seattle, Washington, USA; ${ }^{11}$ Bruno Kessler Foundation, Trento, Italy; ${ }^{12}$ National Center for Atmospheric Research, Boulder, Colorado, USA; ${ }^{13}$ University of Notre Dame, Notre Dame, Indiana, USA; ${ }^{14}$ Institute for Scientific Interchange Foundation, Turin, Italy; ${ }^{15}$ University of California, San Francisco, California, USA.

Corresponding author: Marc Fischer, Arboviral Diseases Branch, Centers for Disease Control and Prevention, Fort Collins, Colorado, mfischer@cdc.gov. 
bioRxiv preprint doi: https://doi.org/10.1101/187591; this version posted September 29, 2017. The copyright holder for this preprint (which was not certified by peer review) is the author/funder, who has granted bioRxiv a license to display the preprint in perpetuity. It is made available under aCC-BY-NC-ND 4.0 International license.

Preliminary modeling results for Zika virus transmission in 2017

September 12, 2017

\begin{abstract}
Numerous Zika virus vaccines are being developed. However, identifying sites to evaluate the efficacy of a Zika virus vaccine is challenging due to the general decrease in Zika virus activity. We compare results from three different modeling approaches to estimate areas that may have increased relative risk of Zika virus transmission during 2017. The analysis focused on eight priority countries (i.e., Brazil, Colombia, Costa Rica, Dominican Republic, Ecuador, Mexico, Panama, and Peru). The models projected low incidence rates during 2017 for all locations in the priority countries but identified several subnational areas that may have increased relative risk of Zika virus transmission in 2017. Given the projected low incidence of disease, the total number of participants, number of study sites, or duration of study follow-up may need to be increased to meet the efficacy study endpoints.
\end{abstract}

\title{
Introduction
}

Zika virus is a mosquito-borne flavivirus primarily transmitted to humans by Aedes (Stegomyia) species mosquitoes [Petersen 2016]. The virus was first identified in Uganda in 1947 [Dick 1952]. Prior to 2007, only sporadic human disease cases were reported from countries in Africa and Asia. From 2007-2014, outbreaks were identified in Southeast Asia and the Western Pacific [Duffy 2009; Heang 2012; Cao-Lormeau 2013; Roth 2014]. In 2015, Zika virus was identified for the first time in the Americas with large outbreaks reported in Brazil and subsequent spread throughout the region [Zanluca 2015; Ikejezie 2017].

Most Zika virus infections are asymptomatic [Duffy 2009]. For patients with symptomatic illness, disease is generally mild and characterized by acute onset of fever or rash. However, Zika virus infection during pregnancy can cause adverse outcomes such as fetal loss, congenital microcephaly, and other serious birth defects [Moore 2017; Rasmussen 2016]. There are no vaccines to prevent Zika virus infection. However, numerous candidate vaccines are being developed and several have entered clinical trials [Thomas 2017].

The National Institutes of Health (NIH) Vaccine Research Center is conducting a Phase 2B clinical trial to evaluate the safety, immunogenicity, and efficacy of a Zika virus DNA vaccine in healthy adolescents and adults. The study will begin in July 2017 and will be performed at multiple sites in the Americas. The current protocol proposes to enroll 2,400 subjects randomized on a 1:1 basis to receive the study vaccine or placebo. Assuming a 50\% vaccine efficacy, the study could be completed in approximately 2 years if the average annual incidence of symptomatic Zika virus disease among participants receiving placebo is $\geq 2 \%$. The sample size or study duration will need to be increased if the symptomatic disease rate among participants is $<2 \%$ or if $>10 \%$ of the participants are already protected at baseline.

Many factors impact the likelihood and rate of ongoing Zika virus infections in a population (e.g., presence and abundance of vector mosquitoes, temperature, precipitation, human mobility, population density, living conditions, and baseline immunity). However, there are limited data and experience for predicting the occurrence and magnitude of future Zika virus disease outbreaks in the Americas. To help with study site selection to meet the efficacy endpoint, NIH and the Centers for Disease Control and Prevention (CDC) requested assistance from three academic groups to adapt and apply existing mathematical models to estimate areas that may have increased likelihood of Zika virus transmission in 2017. Comparing results from three different modeling approaches enables better characterization of the predictive uncertainty due to model and data limitations with higher confidence assigned to predictions for areas where 
bioRxiv preprint doi: https://doi.org/10.1101/187591; this version posted September 29, 2017. The copyright holder for this preprint (which was not certified by peer review) is the author/funder, who has granted bioRxiv a license to display the preprint in perpetuity. It is made available under aCC-BY-NC-ND 4.0 International license.

Preliminary modeling results for Zika virus transmission in 2017

September 12, 2017

model agreement is strong. This report synthesizes findings from the three models obtained in early 2017.

\section{Methods}

We identified three models that had been developed and used to predict the geographic location or incidence of dengue or Zika virus disease in 2015-2016. Each modeling team was tasked with providing a list of areas in the Americas with the highest probability of Zika virus transmission and estimated infection rates during 2017. Each model used different input variables and output measures, and relied on different units of reporting. Therefore, comparisons were limited to subnational areas within the same countries rather than between countries.

To facilitate comparisons between models, data were aggregated to a state/province level and focused on eight priority countries (i.e., Brazil, Colombia, Costa Rica, Dominican Republic, Ecuador, Mexico, Panama, and Peru). These countries were selected based on their capacity and infrastructure to perform clinical trials, and preliminary assessments of expected Zika virus activity based on surveillance reports and previous experience with dengue and chikungunya viruses.

Modeling Team 1 (MT1) ${ }^{1}$

The Global Epidemic and Mobility Model (GLEAM) is a discrete stochastic epidemic computational model based on a meta-population approach in which the world is defined in geographical census areas connected in a network of interactions by human travel fluxes corresponding to transportation infrastructures and mobility patterns [Zhang 2017]. The model includes a multiscale mobility model integrating different layers of transportation networks ranging from long-range airline connections to short-range daily commuting patterns. GLEAM also integrates high-resolution demographic, socioeconomic, temperature, and vector abundance data. The model has been used to analyze the spatiotemporal spread and magnitude of the Zika epidemic in the Americas accounting for seasonal environmental factors and detailed population data. The model is fully stochastic and from any nominally identical initialization (initial conditions and disease model) generates an ensemble of possible epidemic evolutions for epidemic observables, such as newly generated cases, time of arrival of the infection, and number of traveling carriers. The model native grid cell resolution is $25 \mathrm{~km} \mathrm{x} 25 \mathrm{~km}$ and cells are aggregated/projected to the desired level of resolution. For the purpose of studying the Zika outbreak, the model outputs include: 1) the median projected infection rate and $95 \%$ confidence intervals $(95 \% \mathrm{CI})$ for each state/province in the eight priority countries (Tables 1-8); and 2) the probability that an urban area in any country/territory in the Americas will experience an annual Zika virus infection rate $\geq 10 \%$ in 2017 (Table 9).

This modeling approach has been used previously to estimate the transmission and spread of pandemic influenza and Ebola [Tizzoni 2012; Gomes 2014; Poletto 2014]. In order to validate the approach for Zika virus, the authors compared model-based projections to independent surveillance reports of numbers of infections in Colombia, microcephaly cases in Brazil, and travel-associated disease cases in the continental United States and Europe [Zhang 2017].

${ }^{1}$ MT1 includes Alessandro Vespignani, Ana Pastore y Piontti, Kaiyuan Sun, Matteo Chinazzi, M. Elizabeth Halloran, Ira M. Longini, Stefano Merler, Luca Rossi, and Qian Zhang. 
bioRxiv preprint doi: https://doi.org/10.1101/187591; this version posted September 29, 2017. The copyright holder for this preprint (which was not certified by peer review) is the author/funder, who has granted bioRxiv a license to display the preprint in perpetuity. It is made available under aCC-BY-NC-ND 4.0 International license.

Preliminary modeling results for Zika virus transmission in 2017

September 12, 2017

Modeling Team 2 (MT2) $)^{2}$

This approach compares model projections of infection rates with estimates of cumulative infections to date. Locations with a high projected infection rate that have experienced low transmission to date are presumed to be good candidates for vaccine trials because a relatively large portion of the population is still susceptible and likely to become infected before the epidemic subsides. The infection rate projections are informed by spatial layers of variables pertaining to human demography, purchasing power parity, temperature, and vector occurrence probability. Relationships between these variables and infection rates are drawn from the theoretical and empirical literature on other pathogens transmitted by Aedes aegypti mosquitoes, and remaining uncertainties in the model's form are calibrated to seroprevalence estimates following introduction of chikungunya or Zika virus in immunologically naïve populations. The result is a spatial layer of location-specific projections of the number of Zika virus infections that are expected to occur in each $5 \mathrm{~km}$ by $5 \mathrm{~km}$ area across Latin America and the Caribbean [Perkins 2016]. The timeframe for the projected infections is from the beginning of the epidemic until however long it takes for the epidemic to end due to the buildup of sufficient herd immunity. The extent of herd immunity that is sufficient to end the epidemic is positively associated with transmission potential (i.e., a greater proportion of the population must build-up immunity in settings with intense transmission). Although this model does not predict the precise timeframe over which the Zika virus epidemic will run its course, other estimates suggest local epidemics may be extinguished by herd immunity 2-3 years after the initial introduction of Zika virus [Ferguson 2016].

Estimates of cumulative infections to date are based on a combination of cumulative reported cases and assumptions about the proportion of infections that are reported, denoted as $p$. It is generally accepted that $p$ is extremely variable across settings and difficult to ascertain. Based on discussions among the modeling teams, there is general agreement that $p$ may often be around $1-2 \%$, could sometimes be as high as $5 \%$, and is unlikely to exceed $10 \%$ in the settings under consideration. Given this overall uncertainty about $p$ and collective opinion about what values it may likely take, we assumed that $p \sim 0.01+0.9 \operatorname{Beta}(1.2,5)$. This implies that the expected value of $p$ is 0.027 and that it does not exceed 0.1 or fall below 0.01 . This approach to parameterizing $p$ is similar to formulating a prior probability distribution based on "expert opinion" in a Bayesian analysis. For context, we note a limited number of published estimates of p: 0.015 (95\% CI: 0.036-0.022) on Yap Island in 2007 [Duffy 2009]; 0.115 (95\% CI: 0.0730.179) in French Polynesia in 2013-2014 [Kucharski 2016]; 0.021 (95\% CI: 0.017-0.025) in Puerto Rico in 2016 [Chevalier 2017]; and 0.010 (standard deviation $=0.0093$ ) across the Americas as a whole in 2013-2016 [Zhang 2017]. Subsequent refinements of this approach will seek to incorporate additional estimates and to more formally characterize uncertainty about $p$.

The authors then compare the projected number of infections that will occur before the first wave of the epidemic concludes to estimates of the current cumulative incidence of infection to estimate the proportion of the population that remains at risk for infection. Locations with a large discrepancy between numbers of projected total infections and estimated infections to date are interpreted to be good candidates for vaccine trial sites (Tables 1-8).

\footnotetext{
${ }^{2}$ MT2 includes Alex Perkins, Amir Siraj, Christopher Barker, and Robert Reiner.
} 
Modeling Team $3(\mathrm{MT} 3)^{3}$

This approach uses the age-specific incidence of dengue to calculate the associated force of infection for dengue per administrative unit [Cummings 2009; Ferguson 2016; RodriguezBarraquer 2016]. This hazard of infection previously was shown to correlate with Zika incidence in Colombia and with microcephaly incidence in Brazil. In each country, the relationship between dengue force of infection and reported Zika virus disease incidence (Mexico, Colombia) or microcephaly incidence (Brazil) is calculated based on a presumed linear relationship between the square root of Zika incidence (or a proxy) and the force of infection. A statistical probability score per administrative unit is calculated and is the probability of seeing the number of observed cases or greater for a given force of infection, if the square root of incidence is normally distributed with the predicted mean and observed variance of the residuals. This score is used to rank areas, and can be roughly interpreted as the probability of seeing the observed number of cases or fewer if the Zika epidemic has completed in an area with that force of infection for dengue (Tables 1-8).

Integrating the model results

Each province, state, or department in the eight priority countries was ranked according to the primary outcome measure for each of the models that provided data for that country (i.e., all three models for Brazil, Colombia, and Mexico, and models 1 and 2 for Costa Rica, Dominican Republic, Ecuador, Panama, and Peru). The MT3 output was not provided for countries for which age-specific dengue incidence data was unavailable.

The median rank for the available models was calculated and states/provinces were ordered and mapped for each country. The consistency among models was assessed by identifying in each country the states, provinces, or departments ranking within the top quartile by two or more models.

We used data from MT1 to identify states, provinces, or departments with a median projected infection rate $\geq 10 \%$ to approximate a symptomatic infection rate $\geq 2 \%$ in the eight priority countries, assuming that roughly $20 \%$ of cases are symptomatic [Duffy 2009]. We also used Model 1 data to identify municipalities in any country/territory in the Americas with $\geq 5 \%$ probability of having a projected Zika virus infection rate $\geq 10 \%$ in 2017 .

\section{Results}

In order to compare the modeling results, we provide a list of locations (state, province or department) for the eight priority countries, prioritized by the median rank of the models' outcomes. In Tables 1-8 and Figures 1-8 we provide the modeling results of the different models. We show the ranking of the different locations across models and compute a median rank. In addition, we provide the original results of the different models from which we construct the ranking of locations.

The results show that 18 locations (states, provinces, or departments) in six different countries ranked within the top quartile for the given country by two or more models. These locations are the following: Minas Gerais, São Paulo, and Maranhão states in Brazil; Nariño,

\footnotetext{
${ }^{3}$ MT3 includes Justin Lessler, Isabel Rodriguez-Barraquer, Derek Cummings, and Neil Ferguson.
} 
bioRxiv preprint doi: https://doi.org/10.1101/187591; this version posted September 29, 2017. The copyright holder for this preprint (which was not certified by peer review) is the author/funder, who has granted bioRxiv a license to display the preprint in perpetuity. It is made available under aCC-BY-NC-ND 4.0 International license.

Preliminary modeling results for Zika virus transmission in 2017

September 12, 2017

Guajira, Córdoba, Bolívar, and Sucre states in Colombia; Monte Cristi, and Santiago provinces in Dominican Republic; Sucumbios and Los Ríos provinces in Ecuador; Sinaloa, San Luis Potosí, and Tamaulipas states in Mexico; Tumbes, Piura, Ucayali, and San Martin departments in Peru. For Costa Rica and Panama there are no locations ranked within the top quartile by two models. The median rank and range of model ranks (black line) for each state/province within each country are shown in Figure 9. The three models generate a relative ranking in each country; the ranking does not necessarily reflect an absolute risk or infer high virus transmission activity in the top-ranked locations. Locations may have low expected Zika transmission activity but still be ranked in the top places when compared to other places within the same country that show even lower activity.

Only five locations in two countries have a projected median Zika virus infection rate larger than 5\% in 2017: Sucumbios, Esmeraldas, and Orellana provinces in Ecuador; and Tumbes and Piura departments in Peru (see Tables 1-8). When comparing across the three models, three of the previous five locations with a projected Zika virus infection rate larger than $5 \%$, ranked within the top quartile for their country by two or more of the models: Sucumbios in Ecuador and Tumbes and Piura in Peru.

MT1 also offers the possibility of zooming in the different locations, allowing the study of the outbreak at the level of municipalities or urban areas. Through this analysis, we observe that 21 municipalities have a probability larger than $5 \%$ of having a projected Zika virus infection rate of at least 10\% in 2017 (see Table 9). From the municipalities identified by MT1, nine of them are located within regions that are also identified by two or more of the models. The municipalities are the following:

- Colombia: Tumaco in Nariño state.

- Ecuador: Lago Agrio/Nueva Loja in Sucumbios province.

- Mexico: Los Mochis and Culiacan in Sinaloa state, and Tampico in Tamaulipas state.

- Peru: Piura in Piura department, Tumbes in Tumbes department, Tarapoto in San Martín department, and Pacallpa in Ucayali department.

In Figures 1-8, we provide a geographical visualization of the administrative units ranked in the tables. We use a color map associated to the rank order to localize places according to their likelihood of Zika transmission. The purpose of the maps is to illustrate any potential regional clustering of provinces/states with relatively higher likelihood of activity within each country. We again stress that the maps report the median ranking, as obtained by aggregating the results of the three models, and that the ranking is just indicative of the relative likelihood of future transmission within each country.

\section{Summary}

These preliminary findings provide states/provinces and municipalities in eight priority countries where study sites may have increased likelihood of having sufficient Zika virus transmission to meet the efficacy end points in 2017. Due to substantial differences and uncertainties in data between countries, we limited the comparisons to estimates for subnational areas within each of the priority countries.

All of the evaluated subnational areas in the priority countries had low projected incidence rates in 2017. Only three provinces or departments in two countries had a projected Zika virus infection rate $>5 \%$ and ranked within the top quartile for their country by two or more 
bioRxiv preprint doi: https://doi.org/10.1101/187591; this version posted September 29, 2017. The copyright holder for this preprint (which was not certified by peer review) is the author/funder, who has granted bioRxiv a license to display the preprint in perpetuity. It is made available under aCC-BY-NC-ND 4.0 International license.

Preliminary modeling results for Zika virus transmission in 2017

September 12, 2017

of the models. We also identified relatively few municipalities that have a projected Zika virus infection rate $\geq 10 \%$ and are located in states with consistently high rankings by two or more of the models.

In summary, the models suggest that the total number of participants, number of study sites, and/or duration of study follow-up may need to be increased to meet the efficacy end points. The findings also support initiating a high number of study sites in multiple geographic areas to maximize the likelihood of having study capacity in one or more areas that experience Zika virus infections in 2017 and provide flexibility to responsively increase enrollment in areas with the highest incidence of infection

This report is made available to share the approach and preliminary findings with the research community. Results should be interpreted cautiously given the model limitations and assumptions. Furthermore, projecting the Zika virus transmission at seasonal and longer timescales increases uncertainty, especially given the lack of comprehensive, quality surveillance data on current and previous Zika virus transmission activity. The modeling teams are continuing these efforts and will provide an updated report which will incorporate: 1) refined modeling methods, 2) updated surveillance data, and 3) further integration and discussion of similarities and differences between the model findings.

\section{Funding sources}

CMB, TAP, RCR, IRB, and ASS acknowledge support from a RAPID grant from the National Science Foundation (DEB 1641130), and TAP and ASS acknowledge support from a DARPA Young Faculty Award (D16AP00114). MEH, IML and AV are supported by Models of Infectious Disease Agent Study, National Institute of General Medical Sciences Grant U54GM111274. IML is partially supported by the WHO Research and Development Blueprint for Action to Prevent Epidemics. NF acknowledges support from the UK Medical Research Council, the NIGMS MIDAS Initiative and the Bill and Melinda Gates Foundation for research funding. JL and IRB acknowledge support from NIH Grant R01 AI102939-01A1. JL, AP and AV acknowledge support from NIH supplement Grant R01 AI102939-05. AJM acknowledges support to NCAR from a CDC Intergovernmental Personnel Agreement (17IPA1708912); NCAR is also supported by the National Science Foundation.

Competing Interests: AV has received research funding unrelated to this paper (through his employer Northeastern University) from Metabiota Inc.

\section{References}

1. Balcan D, Gonçalves B, Hu H, et al. Modeling the spatial spread of infectious diseases: The global epidemic and mobility computational model. J Computational Sci 2010;1:132-45.

2. Balcan D, Colizza V, Gonçalves B, Hu H, Ramasco JJ, Vespignani A, Multiscale mobility networks and the spatial spreading of infectious diseases. PNAS 2009;106:21484-9.

3. Cao-Lormeau VM, Roche C, Teissier A, et al. Zika virus, French Polynesia, South Pacific. Emerg Infect Dis 2013;20:1085-86.

4. Chevalier MS, Biggerstaff BJ, Basavaraju SV, et al. Use of Blood Donor Screening Data to Estimate Zika Virus Incidence, Puerto Rico, April-August 2016. Emerg Infect Dis 2017;23790-5.

5. Cummings DAT, Iamsirithaworn S, Lessler JT, McDermott A, Prasanthong R, Nisalak A, Jarman RG, Burke DS, Gibbons RV. The impact of the demographic transition on dengue in 
bioRxiv preprint doi: https://doi.org/10.1101/187591; this version posted September 29, 2017. The copyright holder for this preprint (which was not certified by peer review) is the author/funder, who has granted bioRxiv a license to display the preprint in perpetuity. It is made available under aCC-BY-NC-ND 4.0 International license.

Preliminary modeling results for Zika virus transmission in 2017

September 12, 2017

Thailand: Insights from a statistical analysis and mathematical modeling. PLoS Med 2009; 6:e1000139.

6. Dick GWA, Kitchen SF, Haddow AJ. Zika virus. I. Isolations and serological specificity. Trans R Soc Trop Med Hyg 1952;46:509-20.

7. Duffy MR, Chen TH, Hancock WT, et al. Zika virus outbreak on Yap Island, Federated States of Micronesia. N Engl J Med 2009;360;2536-2543.

8. Ferguson NM, Cucunubá ZM, Dorigatti I, et al. Countering the Zika epidemic in Latin America. Science 2016. 10.1126/science.aag0219

9. Gomes M, Pastore-Piontti A, Rossi L, et al. Assessing the international spreading risk associated with the 2014 West African Ebola outbreak. PLoS 2014. doi:10.1371/currents.outbreaks.cd818f63d40e24aef769dda7df9e0da5.

10. Heang V, Yasuda CY, Sovann L, et al. Zika virus infection, Cambodia, 2010. Emerg Infect Dis 2012;18:349.

11. Ikejezie J, Shapiro CN, Kim J, et al. Zika virus transmission - Region of the Americas, May 15, 2015-December 15, 2016. MMWR Morb Mortal Wkly Rep 2017;66:329-34.

12. Kucharski, A.J., Funk, S., Eggo, R.M. et al. Transmission dynamics of Zika virus in island populations: Modeling analysis of the 2013-14 French Polynesia outbreak. PLoS Negl Trop Dis 2016;10:e0004726.

13. Moore CA, Staples JE, Dobyns WB. Characterizing the pattern of anomalies in congenital Zika syndrome for pediatric clinicians. JAMA Pediatr 2017;171:288-95.

14. Musso D, Nilles EJ, Cao-Lormeau VM. Rapid spread of emerging Zika virus in the Pacific area. Clin Microbiol Infect 2014;20:0595-O596.

15. Perkins TA, Siraj AS, Ruktanonchai CW, Kraemer MUG, Tatem AJ. Model-based projections of Zika virus infections in childbearing women in the Americas. Nature Microbiol 2016;16126.

16. Petersen LR, Jamieson DJ, Powers AM, Honein MA`N Engl J Med 2016;374:1552-63.

17. Poletto C, Gomes M, Pastore-Piontti A, et al. Assessing the impact of travel restrictions on international spread of the 2014 West African Ebola epidemic. Eurosurveill 2014;19:20936.

18. Rasmussen SA, Jamieson DJ, Honein MA, Petersen LR. Zika virus and birth defects-Reviewing the evidence for causality. N Engl J Med 2016;374:1981-7.

19. Rodríguez-Barraquer I, Salje H, Lessler J, Cummings DAT. Predicting intensities of Zika infection and microcephaly using transmission intensities of other arboviruses. BioRxiv 2016 http://dx.doi.org/10.1101/041095

20. Roth A, Mercier A, Lepers C, et al. Concurrent outbreaks of dengue, chikungunya and Zika virus infections - An unprecedented epidemic wave of mosquito-borne viruses in the Pacific 2012-2014. Euro Surveill 2014;19.

21. Thomas SJ. Zika virus vaccines - A full field and looking for closers. N Eng J Med 2017;376:1883-6.

22. Tizzoni M, Bajardi P, Poletto C, et al. Real-time numerical forecast of global epidemic spreading: Case study of 2009 A/H1N1pdm. BMC Medicine 2012;10:165.

23. Zanluca C, Melo VCAd, Mosimann ALP, Santos GIVd, Santos CNDd, Luz K. First report of autochthonous transmission of Zika virus in Brazil. Memórias do Instituto Oswaldo Cruz 2015;110:569-572.

24. Zhang Q, Sun K, Chinazzi M, Pastore y Piontti A, et al. Spread of Zika virus in the Americas. PNAS 2017;114:E4334-E4343. 
bioRxiv preprint doi: https://doi.org/10.1101/187591; this version posted September $29,2017$. The copyright holder for this preprint (which was not certified by peer review) is the author/funder, who has granted bioRxiv a license to display the preprint in perpetuity. It is made available under aCC-BY-NC-ND 4.0 International license.

Preliminary modeling results for Zika virus transmission in 2017

September 12, 2017

Table 1: Brazil modeling results by state.

\begin{tabular}{|c|c|c|c|c|c|c|c|c|c|c|}
\hline State & $\begin{array}{c}\text { Median } \\
\text { Rank }\end{array}$ & $\begin{array}{l}\text { MT1 } \\
\text { Rank }\end{array}$ & $\begin{array}{c}\text { MT2 } \\
\text { Rank }\end{array}$ & $\begin{array}{l}\text { MT3 } \\
\text { Rank }\end{array}$ & Population & $\begin{array}{r}\text { MT1* } \\
\text { Infection } \\
\text { rate }\end{array}$ & $(95 \% \mathrm{Cl})$ & $\begin{array}{l}\text { MT2† } \\
\text { Susc. } \\
\text { pop }\end{array}$ & $(95 \% \mathrm{Cl})$ & $\begin{array}{l}\text { MT3 } \\
\text { Score }\end{array}$ \\
\hline Minas Gerais & 1 & 1 & 19 & 1 & $19,987,031$ & $0.06 \%$ & $(0.00-0.35)$ & $13.2 \%$ & $(6.8-21.5)$ & 0.023 \\
\hline São Paulo & 3 & 2 & 26 & 3 & $41,315,532$ & $0.01 \%$ & $(0.00-0.03)$ & $6.0 \%$ & $(4.1-13.3)$ & 0.106 \\
\hline Maranhão & 5 & 12 & 5 & 5 & $6,401,099$ & $<0.01 \%$ & & $32.1 \%$ & $(29.1-35.3)$ & 0.224 \\
\hline Amazonas & 8 & 12 & 3 & - & $3,585,205$ & $<0.01 \%$ & & $33.9 \%$ & $(27.2-40.2)$ & -- \\
\hline Ceará & 8 & 12 & 4 & 8 & $8,382,131$ & $<0.01 \%$ & & $33.5 \%$ & $(30.2-36.4)$ & 0.316 \\
\hline Mato Grosso & 9 & 3 & 27 & 9 & $3,060,605$ & $<0.01 \%$ & $(0.00-0.07)$ & $3.2 \%$ & $(-29.6-20.1)$ & 0.443 \\
\hline Mato Grosso do Sul & 9 & 9 & 7 & 16 & $2,506,342$ & $<0.01 \%$ & $(0.00-0.52)$ & $30.2 \%$ & $(27.0-34.5)$ & 0.676 \\
\hline Pará & 10 & 12 & 10 & 2 & $7,438,518$ & $<0.01 \%$ & & $27.3 \%$ & $(25.1-30.3)$ & 0.03 \\
\hline Rio Grande do Sul & 10 & 10 & 22 & 6 & $10,482,802$ & $<0.01 \%$ & $(0.00-0.03)$ & $11.5 \%$ & $(4.5-19.9)$ & 0.268 \\
\hline Rondônia & 11 & 11 & 17 & 4 & $1,576,505$ & $<0.01 \%$ & $(0.00-0.02)$ & $22.5 \%$ & $(18.5-26.3)$ & 0.124 \\
\hline Rio de Janeiro & 11 & 5 & 21 & 11 & $14,324,781$ & $<0.01 \%$ & $(0.00-0.03)$ & $11.8 \%$ & $(-4.2-20.6)$ & 0.502 \\
\hline Rio Grande do Norte & 12 & 12 & 6 & 20 & $3,023,570$ & $<0.01 \%$ & & $31.5 \%$ & $(26.5-35.2)$ & 0.799 \\
\hline Roraima & 12 & 12 & 1 & 23 & 456,864 & $<0.01 \%$ & & $37.9 \%$ & $(31.3-44.1)$ & 0.962 \\
\hline Piauí & 12 & 12 & 2 & 15 & $3,377,661$ & $<0.01 \%$ & & $36.2 \%$ & $(33.9-39.3)$ & 0.666 \\
\hline Tocantins & 12 & 12 & 14 & 7 & $1,435,936$ & $<0.01 \%$ & & $24.6 \%$ & $(14.7-30.5)$ & 0.275 \\
\hline Distrito Federal & 12 & 12 & 23 & 10 & $2,647,348$ & $<0.01 \%$ & & $7.4 \%$ & $(0.9-18.1)$ & 0.448 \\
\hline Acre & 12 & 12 & 13 & 12 & 708,021 & $<0.01 \%$ & & $26.2 \%$ & $(20.1-30.2)$ & 0.522 \\
\hline Pernambuco & 12 & 12 & 9 & 19 & $7,766,940$ & $<0.01 \%$ & & $29.1 \%$ & $(26.2-32.5)$ & 0.79 \\
\hline Alagoas & 12 & 8 & 12 & 18 & $2,812,590$ & $<0.01 \%$ & $(0.00-0.01)$ & $26.7 \%$ & $(19.3-31.6)$ & 0.761 \\
\hline Sergipe & 12 & 12 & 8 & 21 & $1,991,960$ & $<0.01 \%$ & & $29.9 \%$ & $(27.3-32.3)$ & 0.883 \\
\hline Paraíba & 12 & 12 & 11 & 22 & $3,619,622$ & $<0.01 \%$ & & $27.1 \%$ & $(22.5-31.4)$ & 0.948 \\
\hline Goiás & 13 & 12 & 16 & 13 & $6,205,103$ & $<0.01 \%$ & & $23.9 \%$ & $(18.8-28.8)$ & 0.53 \\
\hline Bahia & 14 & 12 & 20 & 14 & $12,687,903$ & $<0.01 \%$ & & $12.1 \%$ & $(-6.2-22.3)$ & 0.66 \\
\hline Espírito Santo & 15 & 4 & 15 & 17 & $2,682,726$ & $<0.01 \%$ & $(0.00-0.01)$ & $24.4 \%$ & $(19.9-28.3)$ & 0.735 \\
\hline Amapá & 15 & 12 & 18 & -- & 594,387 & $<0.01 \%$ & & $20.7 \%$ & $(17.7-22.8)$ & -- \\
\hline Santa Catarina & 16 & 7 & 24 & -- & $5,417,796$ & $<0.01 \%$ & $(0.00-0.34)$ & $7.3 \%$ & $(2.8-16.1)$ & -- \\
\hline Paraná & 16 & 6 & 25 & -- & $10,616,043$ & $<0.01 \%$ & $(0.00-0.63)$ & $6.8 \%$ & $(4.3-14.8)$ & - \\
\hline
\end{tabular}

*Median and 95\% confidence intervals for projected infection rates in 2017 from $>1,000$ simulations.

$\uparrow$ Proportion of the population still at risk for infection. 
Table 2: Colombia modeling results by state.

\begin{tabular}{|c|c|c|c|c|c|c|c|c|c|c|}
\hline State & $\begin{array}{c}\text { Median } \\
\text { Rank }\end{array}$ & $\begin{array}{l}\text { MT1 } \\
\text { Rank }\end{array}$ & $\begin{array}{l}\text { MT2 } \\
\text { Rank }\end{array}$ & $\begin{array}{l}\text { MT3 } \\
\text { Rank }\end{array}$ & Population & $\begin{array}{r}\text { MT1* } \\
\text { Inf. rate }\end{array}$ & $(95 \% \mathrm{Cl})$ & $\begin{array}{r}\text { MT2† } \\
\text { Susc. pop }\end{array}$ & $(95 \% \mathrm{Cl})$ & $\begin{array}{r}\text { MT3 } \\
\text { Score }\end{array}$ \\
\hline Nariño & 2 & 2 & 19 & 2 & $1,766,008$ & $0.50 \%$ & $(0.04-2.17)$ & $2.7 \%$ & $(1.6-5.7)$ & 0.074 \\
\hline La Guajira & 3 & 1 & 3 & 4 & 985,498 & $0.58 \%$ & $(0.01-3.46)$ & $30.2 \%$ & $(24.1-35.9)$ & 0.137 \\
\hline Córdoba & 4 & 4 & 1 & 11 & $1,736,218$ & $0.26 \%$ & $(0.02-1.00)$ & $33.5 \%$ & $(30.0-37.1)$ & 0.301 \\
\hline Bolívar & 5 & 9 & 4 & 5 & $2,122,021$ & $0.05 \%$ & $(0.00-0.23)$ & $29.8 \%$ & $(23.8-34.4)$ & 0.157 \\
\hline Sucre & 7 & 5 & 7 & 7 & 859,909 & $0.16 \%$ & $(0.01-0.77)$ & $27.3 \%$ & $(17.3-33.5)$ & 0.205 \\
\hline Antioquia & 9 & 8 & 18 & 9 & $6,534,764$ & $0.06 \%$ & $(0.01-0.39)$ & $3.7 \%$ & $(1.0-10.6)$ & 0.227 \\
\hline Guainía & 9 & 13 & 5 & -- & 42,123 & $0.01 \%$ & $(0.00-16.07)$ & $28.8 \%$ & $(25.3-32.0)$ & -- \\
\hline Cauca & 10 & 10 & 15 & 3 & $1,391,889$ & $0.05 \%$ & $(0.00-0.30)$ & $7.8 \%$ & $(5.6-10.2)$ & 0.135 \\
\hline Magdalena & 11 & 6 & 11 & 16 & $1,272,278$ & $0.16 \%$ & $(0.02-0.70)$ & $18.9 \%$ & $(5.0-26.6)$ & 0.561 \\
\hline Cesar & 11 & 11 & 9 & 12 & $1,041,203$ & $0.02 \%$ & $(0.00-0.18)$ & $26.7 \%$ & $(17.6-32.8)$ & 0.330 \\
\hline Vichada & 12 & 12 & 2 & 17 & 73,702 & $0.02 \%$ & $(0.00-10.75)$ & $31.9 \%$ & $(24.3-37.9)$ & 0.620 \\
\hline Choco & 12 & 23 & 12 & 8 & 505,046 & $<0.01 \%$ & & $13.5 \%$ & $(5.4-21.9)$ & 0.222 \\
\hline Caquetá & 13 & 7 & 13 & 19 & 483,834 & $0.06 \%$ & $(0.01-0.36)$ & $9.5 \%$ & $(-4.0-17.5)$ & 0.641 \\
\hline Risaralda & 14 & 14 & 22 & 13 & 957,250 & $<0.01 \%$ & $(0.00-0.03)$ & $0.1 \%$ & $(-8.4-9.6)$ & 0.370 \\
\hline Vaupés & 14 & 17 & 10 & -- & 44,079 & $<0.01 \%$ & $(0.00-1.43)$ & $23.8 \%$ & $(17.4-27.6)$ & -- \\
\hline Atlántico & 14 & 20 & 8 & 14 & $2,489,709$ & $<0.01 \%$ & $(0.00-0.01)$ & $27.1 \%$ & $(12.1-37.0)$ & 0.404 \\
\hline Caldas & 15 & 15 & 20 & 1 & 989,942 & $<0.01 \%$ & $(0.00-0.02)$ & $1.6 \%$ & $(-0.8-5.7)$ & 0.068 \\
\hline Putumayo & 16 & 3 & 16 & 18 & 349,537 & $0.38 \%$ & $(0.03-3.02)$ & $7.3 \%$ & $(-5.1-16.5)$ & 0.632 \\
\hline Guaviare & 16 & 16 & 6 & 21 & 112,621 & $<0.01 \%$ & $(0.00-0.19)$ & $28.6 \%$ & $(17.2-36.4)$ & 0.774 \\
\hline Boyacá & 19 & 19 & 21 & 6 & $1,278,061$ & $<0.01 \%$ & $(0.00-0.01)$ & $1.2 \%$ & $(-0.3-2.1)$ & 0.169 \\
\hline Amazonas & 19 & 23 & 14 & - & 77,088 & $<0.01 \%$ & & $9.0 \%$ & $(-18.3-22.2)$ & -- \\
\hline Meta & 20 & 21 & 17 & 20 & 979,683 & $<0.01 \%$ & $(0.00-0.01)$ & $5.4 \%$ & $(-19.1-17.2)$ & 0.768 \\
\hline Cundinamarca & 23 & 23 & 24 & 15 & $2,721,368$ & $<0.01 \%$ & & $-0.6 \%$ & $(-3.3-0.6)$ & 0.496 \\
\hline Quindío & 23 & 23 & 23 & 10 & 568,473 & $<0.01 \%$ & & $-0.1 \%$ & $(-4.6-11.2)$ & 0.235 \\
\hline Santander & 23 & 23 & 27 & 23 & $2,071,044$ & $<0.01 \%$ & & $-6.6 \%$ & $(-32.9-6.3)$ & 0.829 \\
\hline Tolima & 23 & 23 & 25 & 22 & $1,412,230$ & $<0.01 \%$ & & $-1.5 \%$ & $(-29.1-11.5)$ & 0.793 \\
\hline Huila & 24 & 18 & 29 & 24 & $1,168,910$ & $<0.01 \%$ & $(0.00-0.01)$ & $-9.5 \%$ & $(-41.2-5.2)$ & 0.832 \\
\hline Norte Santander & 25 & 22 & 31 & 25 & $1,367,716$ & $<0.01 \%$ & $(0.00-0.01)$ & $-19.8 \%$ & $(-71.1-4.3)$ & 0.837 \\
\hline Valle & 26 & 23 & 26 & 26 & $4,660,438$ & $<0.01 \%$ & & $-5.2 \%$ & $(-38.8-11.1)$ & 0.871 \\
\hline Arauca & 27 & 23 & 28 & 27 & 265,190 & $<0.01 \%$ & & $-7.1 \%$ & $(-44.2-11.3)$ & 0.962 \\
\hline Casanare & 28 & 23 & 30 & 28 & 362,698 & $<0.01 \%$ & & $-16.7 \%$ & $(-73.6-11.9)$ & 0.993 \\
\hline
\end{tabular}

*Median and 95\% confidence intervals for projected infection rates in 2017 from >1,000 simulations.

$\dagger$ Proportion of the population still at risk for infection. 
bioRxiv preprint doi: https://doi.org/10.1101/187591; this version posted September 29, 2017. The copyright holder for this preprint (which was not certified by peer review) is the author/funder, who has granted bioRxiv a license to display the preprint in perpetuity. It is made available under aCC-BY-NC-ND 4.0 International license.

Preliminary modeling results for Zika virus transmission in 2017

September 12, 2017

Table 3: Costa Rica modeling results by province.

\begin{tabular}{|l|c|c|c|c|r|r|r|r|r|r|}
\hline Province & $\begin{array}{c}\text { Median } \\
\text { Rank }\end{array}$ & $\begin{array}{r}\text { MT1 } \\
\text { Rank }\end{array}$ & $\begin{array}{c}\text { MT2 } \\
\text { Rank }\end{array}$ & $\begin{array}{r}\text { MT3 } \\
\text { Rank }\end{array}$ & Population & $\begin{array}{r}\text { MT1* } \\
\text { Inf. rate }\end{array}$ & (95\% Cl) & $\begin{array}{r}\text { MT2† } \\
\text { Susc. } \\
\text { pop }\end{array}$ & $\begin{array}{r}\text { (95\%CI) } \\
\text { ST3 }\end{array}$ \\
\hline Limon & 3 & 2 & 4 & -- & 386,862 & $<0.01 \%$ & $(0.00-3.99)$ & $3.0 \%$ & $(-0.7-13.8)$ \\
\hline Puntarenas & 3 & 3 & 2 & -- & 410,929 & $<0.01 \%$ & $(0.00-1.03)$ & $7.8 \%$ & $(-0.6-15.7)$ \\
\hline Guanacaste & 3 & 5 & 1 & -- & 354,154 & $<0.01 \%$ & & $16.5 \%$ & $(10.6-22.1)$ \\
\hline Cartago & 4 & 1 & 7 & -- & 490,903 & $<0.01 \%$ & $(0.00-1.51)$ & $0.8 \%$ & $(0.2-3.5)$ \\
\hline Alajuela & 4 & 5 & 3 & -- & 885,571 & $<0.01 \%$ & & $6.1 \%$ & $(3.1-15.3)$ \\
\hline San Jose & 5 & 4 & 6 & -- & $1,404,242$ & $<0.01 \%$ & $(0.00-0.38)$ & $1.3 \%$ & $(0.1-7.8)$ \\
\hline Heredia & 5 & 5 & 5 & -- & 433,677 & $<0.01 \%$ & & $1.8 \%$ & $(0.5-10.1)$ \\
\hline
\end{tabular}

*Median and 95\% confidence intervals for projected infection rates in 2017 from >1,000 simulations.

$\dagger$ Proportion of the population still at risk for infection. 
bioRxiv preprint doi: https://doi.org/10.1101/187591; this version posted September $29,2017$. The copyright holder for this preprint (which was not certified by peer review) is the author/funder, who has granted bioRxiv a license to display the preprint in perpetuity. It is made available under aCC-BY-NC-ND 4.0 International license.

Preliminary modeling results for Zika virus transmission in 2017

September 12, 2017

Table 4: Dominican Republic modeling results by province.

\begin{tabular}{|c|c|c|c|c|c|c|c|c|c|c|}
\hline Province & $\begin{array}{c}\text { Median } \\
\text { Rank }\end{array}$ & $\begin{array}{l}\text { MT1 } \\
\text { Rank }\end{array}$ & $\begin{array}{c}\text { MT2 } \\
\text { Rank }\end{array}$ & $\begin{array}{l}\text { MT3 } \\
\text { Rank }\end{array}$ & Population & $\begin{array}{l}\text { MT1* } \\
\text { Inf. rate }\end{array}$ & $(95 \% \mathrm{Cl})$ & $\begin{array}{r}\text { MT2 } † \\
\text { Susc. } \\
\text { pop }\end{array}$ & $(95 \% \mathrm{Cl})$ & $\begin{array}{r}\text { MT3 } \\
\text { Score }\end{array}$ \\
\hline Monte Cristi & 2 & 1 & 3 & -- & 116,848 & $<0.01 \%$ & $(0.00-0.01)$ & $33.9 \%$ & $(30.6-37.4)$ & \\
\hline Santiago & 4 & 6 & 2 & -- & 970,653 & $<0.01 \%$ & $(0.00-0.01)$ & $34.1 \%$ & $(30.2-37.9)$ & \\
\hline Valverde & 6 & 10 & 1 & -- & 162,117 & $<0.01 \%$ & $(0.00-0.01)$ & $34.9 \%$ & $(30.9-39.2)$ & \\
\hline Espaillat & 7 & 3 & 10 & -- & 301,254 & $<0.01 \%$ & $(0.00-0.01)$ & $31.6 \%$ & $(29.0-33.8)$ & \\
\hline Sánchez Ramírez & 7 & 8 & 6 & -- & 182,808 & $<0.01 \%$ & $(0.00-0.01)$ & $33.0 \%$ & $(29.9-36.0)$ & \\
\hline Hermanas Mirabal & 8 & 2 & 14 & -- & 96,647 & $<0.01 \%$ & $(0.00-0.01)$ & $30.2 \%$ & $(27.3-33.0)$ & \\
\hline La Romana & 9 & 14 & 4 & -- & 196,134 & $<0.01 \%$ & & $33.3 \%$ & $(29.7-36.8)$ & \\
\hline Duarte & 10 & 11 & 9 & -- & 318,669 & $<0.01 \%$ & $(0.00-0.01)$ & $31.7 \%$ & $(28.9-35.4)$ & \\
\hline Dajabón & 10 & 12 & 8 & -- & 137,343 & $<0.01 \%$ & $(0.00-0.01)$ & $32.9 \%$ & $(30.1-36.0)$ & \\
\hline Monseñor Nouel & 10 & 14 & 6 & -- & 159,403 & $<0.01 \%$ & & $33.0 \%$ & $(29.4-37.0)$ & \\
\hline San Pedro de Macorís & 10 & 14 & 5 & -- & 230,075 & $<0.01 \%$ & & $33.2 \%$ & $(29.2-36.9)$ & \\
\hline Puerto Plata & 11 & 5 & 16 & -- & 304,307 & $<0.01 \%$ & $(0.00-0.01)$ & $29.1 \%$ & $(27.4-31.3)$ & \\
\hline Baoruco & 12 & 14 & 10 & -- & 98,386 & $<0.01 \%$ & & $31.6 \%$ & $(29.6-34.4)$ & \\
\hline Santiago Rodríguez & 13 & 13 & 13 & -- & 57,191 & $<0.01 \%$ & $(0.00-0.01)$ & $30.3 \%$ & $(28.8-32.7)$ & \\
\hline María Trinidad Sánchez & 13 & 14 & 12 & -- & 129,287 & $<0.01 \%$ & & $30.9 \%$ & $(28.7-33.1)$ & \\
\hline San Juan & 14 & 4 & 23 & -- & 244,052 & $<0.01 \%$ & $(0.00-0.01)$ & $25.4 \%$ & $(22.3-28.5)$ & \\
\hline La Vega & 14 & 7 & 20 & -- & 372,969 & $<0.01 \%$ & $(0.00-0.01)$ & $25.9 \%$ & $(23.6-28.8)$ & \\
\hline La Estrelleta/Elias Pina & 15 & 9 & 21 & -- & 86,066 & $<0.01 \%$ & $(0.00-0.01)$ & $25.8 \%$ & $(23.1-28.7)$ & \\
\hline San Cristóbal & 15 & 14 & 15 & -- & 446,468 & $<0.01 \%$ & & $29.9 \%$ & $(27.9-32.0)$ & \\
\hline Monte Plata & 16 & 14 & 17 & -- & 206,972 & $<0.01 \%$ & & $27.7 \%$ & $(24.8-30.2)$ & \\
\hline Peravia & 16 & 14 & 18 & -- & 175,038 & $<0.01 \%$ & & $26.6 \%$ & $(24.5-28.8)$ & \\
\hline La Altagracia & 17 & 14 & 19 & -- & 263,460 & $<0.01 \%$ & & $26.2 \%$ & $(21.8-28.9)$ & \\
\hline El Seibo & 18 & 14 & 22 & -- & 92,467 & $<0.01 \%$ & & $25.7 \%$ & $(21.0-28.2)$ & \\
\hline Barahona & 19 & 14 & 24 & -- & 143,242 & $<0.01 \%$ & & $25.3 \%$ & $(23.4-27.7)$ & \\
\hline Azua & 20 & 14 & 25 & -- & 221,137 & $<0.01 \%$ & & $24.8 \%$ & $(22.5-26.4)$ & \\
\hline Independencia & 20 & 14 & 26 & -- & 62,587 & $<0.01 \%$ & & $24.6 \%$ & $(22.5-26.9)$ & \\
\hline Hato Mayor & 21 & 14 & 28 & -- & 75,665 & $<0.01 \%$ & & $23.2 \%$ & $(18.3-27.4)$ & \\
\hline Santo Domingo & 21 & 14 & 27 & -- & $2,559,326$ & $<0.01 \%$ & & $23.6 \%$ & $(21.0-25.8)$ & \\
\hline Distrito Nacional & 22 & 14 & 30 & -- & 845,598 & $<0.01 \%$ & & $18.2 \%$ & $(15.4-21.2)$ & \\
\hline Samaná & 22 & 14 & 29 & -- & 88,288 & $<0.01 \%$ & & $20.3 \%$ & $(16.8-23.2)$ & \\
\hline San José de Ocoa & 22 & 14 & 32 & -- & 58,322 & $<0.01 \%$ & & $0.9 \%$ & $(-0.7-11.0)$ & \\
\hline Pedernales & 23 & 14 & 31 & -- & 44,944 & $<0.01 \%$ & & $17.2 \%$ & $(15.1-20.3)$ & \\
\hline
\end{tabular}

*Median and $95 \%$ confidence intervals for projected infection rates in 2017 from $>1,000$ simulations.

$\dagger$ Proportion of the population still at risk for infection. 
bioRxiv preprint doi: https://doi.org/10.1101/187591; this version posted September $29,2017$. The copyright holder for this preprint (which was not certified by peer review) is the author/funder, who has granted bioRxiv a license to display the preprint in perpetuity. It is made available under aCC-BY-NC-ND 4.0 International license.

Preliminary modeling results for Zika virus transmission in 2017

September 12, 2017

Table 5: Ecuador modeling results by province.

\begin{tabular}{|c|c|c|c|c|c|c|c|c|c|c|}
\hline Province & $\begin{array}{c}\text { Median } \\
\text { Rank }\end{array}$ & $\begin{array}{l}\text { MT1 } \\
\text { Rank }\end{array}$ & $\begin{array}{l}\text { MT2 } \\
\text { Rank }\end{array}$ & $\begin{array}{l}\text { MT3 } \\
\text { Rank }\end{array}$ & Population & $\begin{array}{r}\text { MT1* } \\
\text { Inf. rate }\end{array}$ & $(95 \% \mathrm{Cl})$ & $\begin{array}{r}\text { MT2† } \\
\text { Susc. } \\
\text { pop }\end{array}$ & $(95 \% \mathrm{Cl})$ & $\begin{array}{r}\text { MT3 } \\
\text { Score }\end{array}$ \\
\hline Sucumbíos & 4 & 1 & 6 & -- & 186,504 & $7.55 \%$ & $(0.21-15.90)$ & $14.8 \%$ & $(6.6-24.4)$ & \\
\hline Los Ríos & 5 & 5 & 4 & -- & 777,079 & $0.81 \%$ & $(0.07-3.59)$ & $18.6 \%$ & $(12.9-24.9)$ & \\
\hline Esmeraldas & 5 & 2 & 8 & -- & 555,848 & $5.81 \%$ & $(0.43-12.96)$ & $12.0 \%$ & $(5.3-21.2)$ & \\
\hline Orellana & 6 & 3 & 9 & -- & 88,611 & $5.43 \%$ & $(0.38-12.54)$ & $8.6 \%$ & $(4.1-19.9)$ & \\
\hline Manabí & 7 & 6 & 7 & -- & $1,281,663$ & $0.55 \%$ & $(0.05-1.83)$ & $13.0 \%$ & $(2.5-21.3)$ & \\
\hline Guayas & 7 & 11 & 2 & -- & $3,595,034$ & $0.02 \%$ & $(0.00-0.13)$ & $27.7 \%$ & $(24.4-30.4)$ & \\
\hline El Oro & 8 & 13 & 3 & -- & 613,666 & $<0.01 \%$ & $(0.00-0.62)$ & $23.0 \%$ & $(18.9-27.3)$ & \\
\hline Santa Elena & 8 & 15 & 1 & -- & 292,220 & $<0.01 \%$ & $(0.00-0.01)$ & $30.0 \%$ & $(27.0-32.8)$ & \\
\hline Pastaza & 9 & 4 & 14 & -- & 87,380 & $3.07 \%$ & $(0.49-6.55)$ & $2.8 \%$ & $(1.1-12.3)$ & \\
\hline Bolívar & 12 & 7 & 16 & -- & 200,410 & $0.51 \%$ & $(0.04-2.36)$ & $1.4 \%$ & $(0.3-6.3)$ & \\
\hline Napo & 12 & 8 & 16 & -- & 106,649 & $0.48 \%$ & $(0.06-1.30)$ & $1.4 \%$ & $(0.2-10.8)$ & \\
\hline Morona Santiago & 12 & 12 & 12 & -- & 153,622 & $0.02 \%$ & $(0.00-0.31)$ & $5.6 \%$ & $(2.2-16.2)$ & \\
\hline Galápagos & 12 & 19 & 5 & -- & 20,541 & $<0.01 \%$ & & $16.6 \%$ & $(10.6-21.6)$ & \\
\hline Cotopaxi & 14 & 10 & 18 & -- & 394,132 & $0.24 \%$ & $(0.02-1.21)$ & $0.7 \%$ & $(0.1-2.7)$ & \\
\hline Cañar & 14 & 17 & 10 & -- & 234,668 & $<0.01 \%$ & $(0.00-0.02)$ & $6.9 \%$ & $(5.0-8.7)$ & \\
\hline Carchi & 15 & 9 & 20 & -- & 155,648 & $0.34 \%$ & $(0.00-1.64)$ & $0.0 \%$ & $(0.0-0.3)$ & \\
\hline Zamora Chinchipe & 15 & 14 & 15 & -- & 105,214 & $<0.01 \%$ & $(0.00-0.24)$ & $2.2 \%$ & $(0.2-13.3)$ & \\
\hline Loja & 15 & 16 & 13 & -- & 450,634 & $<0.01 \%$ & $(0.00-0.17)$ & $3.6 \%$ & $(2.3-7.6)$ & \\
\hline $\begin{array}{l}\text { Santo Domingo } \\
\text { Tsáchilas }\end{array}$ & 15 & 19 & 11 & -- & 422,080 & $<0.01 \%$ & & $6.0 \%$ & $(1.6-17.8)$ & \\
\hline Azuay & 18 & 18 & 18 & -- & 726,744 & $<0.01 \%$ & $(0.00-0.03)$ & $0.7 \%$ & $(0.5-1.1)$ & \\
\hline Chimborazo & 20 & 19 & 20 & -- & 468,077 & $<0.01 \%$ & & $0.0 \%$ & $(0.0-0.2)$ & \\
\hline Imbabura & 20 & 19 & 20 & -- & 394,164 & $<0.01 \%$ & & $0.0 \%$ & $(0.0-0.3)$ & \\
\hline Pichincha & 20 & 19 & 20 & -- & $2,449,094$ & $<0.01 \%$ & & $0.0 \%$ & $(-0.1-0.3)$ & \\
\hline Tungurahua & 20 & 19 & 20 & -- & 530,294 & $<0.01 \%$ & & $0.0 \%$ & $(0.0-0.0)$ & \\
\hline
\end{tabular}

*Median and 95\% confidence intervals for projected infection rates in 2017 from >1,000 simulations.

$\uparrow$ Proportion of the population still at risk for infection. 
bioRxiv preprint doi: https://doi.org/10.1101/187591; this version posted September $29,2017$. The copyright holder for this preprint (which was not certified by peer review) is the author/funder, who has granted bioRxiv a license to display the preprint in perpetuity. It is made available under aCC-BY-NC-ND 4.0 International license.

Preliminary modeling results for Zika virus transmission in 2017

September 12, 2017

Table 6: Mexico modeling results by state

\begin{tabular}{|c|c|c|c|c|c|c|c|c|c|c|}
\hline State & $\begin{array}{c}\text { Median } \\
\text { Rank }\end{array}$ & $\begin{array}{l}\text { MT1 } \\
\text { Rank }\end{array}$ & $\begin{array}{c}\text { MT2 } \\
\text { Rank }\end{array}$ & $\begin{array}{l}\text { MT3 } \\
\text { Rank }\end{array}$ & Population & $\begin{array}{r}\text { MT1* } \\
\text { Inf. } \\
\text { rate }\end{array}$ & $(95 \% \mathrm{Cl})$ & $\begin{array}{r}\text { MT2† } \\
\text { Susc. } \\
\text { pop }\end{array}$ & $(95 \% \mathrm{Cl})$ & $\begin{array}{r}\text { MT3 } \\
\text { Score }\end{array}$ \\
\hline Sinaloa & 1 & 1 & 1 & 4 & $2,838,630$ & $2.44 \%$ & $(0.02-14.95)$ & $38.5 \%$ & $(31.2-44.1)$ & 0.166 \\
\hline San Luis Potosí & 4 & 4 & 19 & 1 & $2,626,925$ & $0.33 \%$ & $(0.00-4.29)$ & $10.0 \%$ & $(9.0-10.9)$ & 0.002 \\
\hline Tamaulipas & 5 & 5 & 2 & 7 & $2,684,165$ & $0.28 \%$ & $(0.00-3.86)$ & $37.4 \%$ & $(29.7-42.6)$ & 0.286 \\
\hline Sonora & 9 & 3 & 9 & 14 & $2,663,174$ & $0.58 \%$ & $(0.03-1.65)$ & $29.1 \%$ & $(25.5-32.8)$ & 0.552 \\
\hline Quintana Roo & 10 & 10 & 7 & 19 & $1,127,393$ & $0.03 \%$ & $(0.00-1.56)$ & $30.6 \%$ & $(25.5-34.1)$ & 0.695 \\
\hline Baja California Sur & 11 & 2 & 11 & 17 & 569,628 & $1.55 \%$ & $(0.12-4.85)$ & $25.4 \%$ & $(22.4-28.4)$ & 0.622 \\
\hline Nayarit & 11 & 8 & 12 & 11 & $10,443,171$ & $0.05 \%$ & $(0.00-11.01)$ & $24.7 \%$ & $(20.6-27.7)$ & 0.405 \\
\hline Campeche & 12 & 12 & 6 & 22 & 799,030 & $0.02 \%$ & $(0.00-1.29)$ & $30.9 \%$ & $(24.9-35.2)$ & 0.797 \\
\hline Nuevo León & 12 & 21 & 3 & 12 & $4,881,286$ & $<0.01 \%$ & $(0.00-0.29)$ & $35.1 \%$ & $(27.5-40.1)$ & 0.468 \\
\hline Veracruz & 14 & 6 & 14 & 26 & $7,620,285$ & $0.18 \%$ & $(0.00-4.59)$ & $21.5 \%$ & $(19.8-22.9)$ & 0.936 \\
\hline Guerrero & 14 & 14 & 10 & 21 & $3,479,330$ & $0.01 \%$ & $(0.00-2.08)$ & $26.8 \%$ & $(24.8-28.8)$ & 0.754 \\
\hline Chihuahua & 15 & 13 & 17 & -- & $3,309,967$ & $0.01 \%$ & $(0.00-0.06)$ & $15.4 \%$ & $(8.9-18.9)$ & -- \\
\hline Colima & 15 & 15 & 7 & 25 & 671,505 & $0.01 \%$ & $(0.00-18.45)$ & $30.6 \%$ & $(26.4-34.1)$ & 0.846 \\
\hline Coahuila & 15 & 25 & 15 & 15 & $3,197,854$ & $<0.01 \%$ & $(0.00-0.01)$ & $20.0 \%$ & $(15.4-22.9)$ & 0.614 \\
\hline Chiapas & 16 & 9 & 16 & 16 & $4,960,867$ & $0.04 \%$ & $(0.00-2.50)$ & $15.8 \%$ & $(14.0-20.1)$ & 0.615 \\
\hline Jalisco & 16 & 16 & 21 & 8 & $7,708,204$ & $0.01 \%$ & $(0.00-1.61)$ & $6.4 \%$ & $(3.2-18.2)$ & 0.331 \\
\hline Michoacán & 17 & 17 & 20 & 2 & $4,448,339$ & $0.01 \%$ & $(0.00-6.27)$ & $6.8 \%$ & $(6.2-9.2)$ & 0.023 \\
\hline Oaxaca & 18 & 7 & 18 & 20 & $3,846,384$ & $0.11 \%$ & $(0.00-5.65)$ & $13.0 \%$ & $(11.5-17.5)$ & 0.697 \\
\hline Hidalgo & 18 & 11 & 24 & 18 & $3,058,115$ & $0.02 \%$ & $(0.00-0.42)$ & $3.6 \%$ & $(2.7-4.5)$ & 0.651 \\
\hline Durango & 18 & 18 & 22 & 6 & $1,315,740$ & $<0.01 \%$ & $(0.00-1.24)$ & $4.8 \%$ & $(3.4-15.0)$ & 0.280 \\
\hline Tabasco & 19 & 19 & 5 & 23 & $2,301,101$ & $<0.01 \%$ & $(0.00-0.80)$ & $32.3 \%$ & $(28.9-35.7)$ & 0.808 \\
\hline Puebla & 20 & 20 & 25 & 9 & $6,319,334$ & $<0.01 \%$ & $(0.00-0.73)$ & $2.8 \%$ & $(2.3-4.3)$ & 0.354 \\
\hline Yucatán & 22 & 22 & 4 & 27 & $2,018,565$ & $<0.01 \%$ & $(0.00-0.04)$ & $33.3 \%$ & $(28.1-37.4)$ & 0.957 \\
\hline Zacatecas & 23 & 23 & 28 & 13 & $1,582,975$ & $<0.01 \%$ & $(0.00-0.06)$ & $0.6 \%$ & $(0.3-3.6)$ & 0.507 \\
\hline Guanajuato & 23 & 24 & 23 & 10 & $5,825,418$ & $<0.01 \%$ & $(0.00-0.07)$ & $4.1 \%$ & $(0.5-15.1)$ & 0.382 \\
\hline Morelos & 24 & 26 & 13 & 24 & $1,876,080$ & $<0.01 \%$ & & $23.2 \%$ & $(19.2-27.4)$ & 0.837 \\
\hline Baja California & 26 & 26 & 26 & -- & $3,059,921$ & $<0.01 \%$ & & $1.5 \%$ & $(0.8-10.2)$ & -- \\
\hline México & 26 & 26 & 30 & 3 & $17,214,830$ & $<0.01 \%$ & & $0.2 \%$ & $(0.2-0.4)$ & 0.143 \\
\hline Querétaro & 26 & 26 & 27 & 5 & $1,932,829$ & $<0.01 \%$ & & $0.9 \%$ & $(0.7-4.2)$ & 0.272 \\
\hline Aguascalientes & 28 & 26 & 29 & -- & $1,206,312$ & $<0.01 \%$ & & $0.5 \%$ & $(0.0-12.9)$ & \\
\hline Distrito Federal & 29 & 26 & 31 & -- & $7,924,645$ & $<0.01 \%$ & & $0.0 \%$ & $(0.0-0.0)$ & \\
\hline Tlaxcala & 29 & 26 & 31 & -- & $1,066,673$ & $<0.01 \%$ & & $0.0 \%$ & $(0.0-0.0)$ & \\
\hline
\end{tabular}

*Median and 95\% confidence intervals for projected infection rates in 2017 from > 1,000 simulations.

$\uparrow$ Proportion of the population still at risk for infection. 
bioRxiv preprint doi: https://doi.org/10.1101/187591; this version posted September 29, 2017. The copyright holder for this preprint (which was not certified by peer review) is the author/funder, who has granted bioRxiv a license to display the preprint in perpetuity. It is made available under aCC-BY-NC-ND 4.0 International license.

Preliminary modeling results for Zika virus transmission in 2017

September 12, 2017

Table 7: Panama results by province

\begin{tabular}{|c|c|c|c|c|c|c|c|c|c|c|}
\hline Province & $\begin{array}{l}\text { Median } \\
\text { Rank }\end{array}$ & $\begin{array}{l}\text { MT1 } \\
\text { Rank }\end{array}$ & $\begin{array}{l}\text { MT2 } \\
\text { Rank }\end{array}$ & $\begin{array}{l}\text { MT3 } \\
\text { Rank }\end{array}$ & Population & $\begin{array}{r}\text { MT1* } \\
\text { Inf. } \\
\text { rate }\end{array}$ & $(95 \% \mathrm{Cl})$ & $\begin{array}{r}\text { MT2† } \\
\text { Susc. } \\
\text { pop }\end{array}$ & $(95 \% \mathrm{Cl})$ & $\begin{array}{r}\text { MT3 } \\
\text { Score }\end{array}$ \\
\hline Herrera & 4 & 7 & 1 & -- & 99,504 & $<0.01 \%$ & $(0.00-0.13)$ & $30.3 \%$ & $(27.5-33.6)$ & \\
\hline Los Santos & 5 & 8 & 2 & -- & 107,876 & $<0.01 \%$ & $(0.00-0.01)$ & $29.3 \%$ & $(26.9-31.7)$ & \\
\hline Emberá & 6 & 4 & 8 & -- & 34,319 & $0.01 \%$ & $(0.00-0.45)$ & $19.3 \%$ & $(12.0-25.3)$ & \\
\hline Veraguas & 6 & 5 & 6 & -- & 225,085 & $<0.01 \%$ & $(0.00-0.14)$ & $23.2 \%$ & $(18.2-25.8)$ & \\
\hline Ngäbe Buglé & 7 & 1 & 12 & -- & 152,129 & $0.02 \%$ & $(0.00-0.47)$ & $5.1 \%$ & $(2.5-15.1)$ & \\
\hline $\begin{array}{l}\text { Bocas del } \\
\text { Toro }\end{array}$ & 7 & 2 & 11 & -- & 106,106 & $0.02 \%$ & $(0.00-0.59)$ & $11.3 \%$ & $(6.8-16.4)$ & \\
\hline Darién & 7 & 3 & 10 & -- & 46,615 & $0.01 \%$ & $(0.00-0.68)$ & $14.0 \%$ & $(8.1-22.0)$ & \\
\hline Panamá & 7 & 11 & 3 & -- & $1,207,922$ & $<0.01 \%$ & & $25.5 \%$ & $(23.4-27.5)$ & \\
\hline Colón & 8 & 9 & 7 & -- & 221,879 & $<0.01 \%$ & $(0.00-0.00)$ & $21.6 \%$ & $(18.2-24.7)$ & \\
\hline Chiriquí & 8 & 6 & 9 & -- & 437,495 & $<0.01 \%$ & $(0.00-0.12)$ & $17.2 \%$ & $(13.9-20.1)$ & \\
\hline Coclé & 8 & 11 & 4 & -- & 218,284 & $<0.01 \%$ & & $24.8 \%$ & $(22.2-26.4)$ & \\
\hline $\begin{array}{l}\text { Panamá } \\
\text { Oeste }\end{array}$ & 8 & 11 & 5 & -- & 358,910 & $<0.01 \%$ & & $24.5 \%$ & $(21.8-26.4)$ & \\
\hline Guna Yala & 12 & 10 & 13 & -- & 3,808 & $<0.01 \%$ & $(0.00-0.13)$ & $-183.3 \%$ & $(-427.6--61.6)$ & \\
\hline
\end{tabular}

*Median and 95\% confidence intervals for projected infection rates in 2017 from > 1,000 simulations.

$\uparrow$ Proportion of the population still at risk for infection. 
bioRxiv preprint doi: https://doi.org/10.1101/187591; this version posted September $29,2017$. The copyright holder for this preprint (which was not certified by peer review) is the author/funder, who has granted bioRxiv a license to display the preprint in perpetuity. It is made available under aCC-BY-NC-ND 4.0 International license.

Preliminary modeling results for Zika virus transmission in 2017

September 12, 2017

Table 8: Peru modeling results by department.

\begin{tabular}{|c|c|c|c|c|c|c|c|c|c|c|}
\hline Department & $\begin{array}{c}\text { Median } \\
\text { Rank }\end{array}$ & $\begin{array}{l}\text { MT1 } \\
\text { Rank }\end{array}$ & $\begin{array}{c}\text { MT2 } \\
\text { Rank }\end{array}$ & $\begin{array}{l}\text { MT3 } \\
\text { Rank }\end{array}$ & Population & $\begin{array}{r}\text { MT1* } \\
\text { Inf. rate }\end{array}$ & $(95 \% \mathrm{Cl})$ & $\begin{array}{r}\text { MT2† } \\
\text { Susc. } \\
\text { pop }\end{array}$ & $(95 \% \mathrm{Cl})$ & $\begin{array}{r}\text { MT3 } \\
\text { Score }\end{array}$ \\
\hline Tumbes & 2 & 2 & 2 & -- & 193,544 & $6.31 \%$ & $(0.00-35.76)$ & $29.7 \%$ & $(26.9-32.6)$ & \\
\hline Piura & 3 & 1 & 4 & - & $1,707,749$ & $7.10 \%$ & $(0.00-22.54)$ & $18.9 \%$ & $(15.5-24.5)$ & \\
\hline Loreto & 4 & 7 & 1 & -- & 976,542 & $0.03 \%$ & $(0.00-8.14)$ & $30.7 \%$ & $(25.2-33.8)$ & \\
\hline Ucayali & 5 & 6 & 3 & -- & 464,972 & $0.06 \%$ & $(0.00-23.78)$ & $28.4 \%$ & $(25.4-31.7)$ & \\
\hline San Martín & 5 & 4 & 6 & -- & 774,056 & $0.10 \%$ & $(0.00-24.73)$ & $16.8 \%$ & $(11.8-24.2)$ & \\
\hline Lambayeque & 6 & 5 & 7 & -- & $1,140,486$ & $0.06 \%$ & $(0.00-0.32)$ & $10.7 \%$ & $(5.1-22.2)$ & \\
\hline Cajamarca & 8 & 3 & 12 & -- & $1,455,633$ & $0.17 \%$ & $(0.00-0.81)$ & $2.6 \%$ & $(1.7-5.1)$ & \\
\hline Madre de Dios & 8 & 10 & 5 & -- & 121,804 & $<0.01 \%$ & & $18.1 \%$ & $(12.9-24.2)$ & \\
\hline Amazonas & 9 & 10 & 8 & -- & 427,666 & $<0.01 \%$ & & $8.2 \%$ & $(5.9-13.6)$ & \\
\hline Callao & 10 & 10 & 9 & -- & 260,540 & $<0.01 \%$ & & $4.0 \%$ & $(0.0-18.6)$ & \\
\hline Junín & 10 & 10 & 10 & -- & $1,249,333$ & $<0.01 \%$ & & $2.8 \%$ & $(1.6-5.2)$ & \\
\hline Lima Province & 10 & 10 & 10 & -- & $7,957,501$ & $<0.01 \%$ & & $2.8 \%$ & $(0.0-14.6)$ & \\
\hline Huánuco & 11 & 8 & 13 & -- & 817,699 & $<0.01 \%$ & $(0.00-1.11)$ & $2.5 \%$ & $(1.4-5.6)$ & \\
\hline Pasco & 12 & 9 & 14 & -- & 286,905 & $<0.01 \%$ & $(0.00-0.14)$ & $1.9 \%$ & $(1.1-4.2)$ & \\
\hline Cuzco & 13 & 10 & 15 & -- & $1,255,116$ & $<0.01 \%$ & & $1.0 \%$ & $(0.6-2.0)$ & \\
\hline La Libertad & 13 & 10 & 16 & -- & $1,723,072$ & $<0.01 \%$ & & $0.8 \%$ & $(0.1-7.6)$ & \\
\hline Ayacucho & 14 & 10 & 18 & -- & 651,575 & $<0.01 \%$ & & $0.3 \%$ & $(0.2-0.9)$ & \\
\hline Lima & 14 & 10 & 17 & -- & $1,462,706$ & $<0.01 \%$ & & $0.4 \%$ & $(0.0-4.6)$ & \\
\hline Ancash & 15 & 10 & 20 & -- & $1,097,634$ & $<0.01 \%$ & & $0.1 \%$ & $(0.0-4.0)$ & \\
\hline Puno & 15 & 10 & 19 & - & $1,488,142$ & $<0.01 \%$ & & $0.2 \%$ & $(0.1-0.5)$ & \\
\hline Apurímac & 16 & 10 & 21 & -- & 434,423 & $<0.01 \%$ & & $0.0 \%$ & $(0.0-0.0)$ & \\
\hline Arequipa & 16 & 10 & 21 & -- & $1,187,531$ & $<0.01 \%$ & & $0.0 \%$ & $(0.0-0.0)$ & \\
\hline Huancavelica & 16 & 10 & 21 & -- & 491,764 & $<0.01 \%$ & & $0.0 \%$ & $(0.0-0.0)$ & \\
\hline Ica & 16 & 10 & 21 & -- & 719,368 & $<0.01 \%$ & & $0.0 \%$ & $(0.0-3.3)$ & \\
\hline Moquegua & 16 & 10 & 21 & -- & 173,112 & $<0.01 \%$ & & $0.0 \%$ & $(0.0-0.1)$ & \\
\hline Tacna & 16 & 10 & 21 & -- & 308,111 & $<0.01 \%$ & & $0.0 \%$ & $(0.0-0.1)$ & \\
\hline
\end{tabular}

*Median and 95\% confidence intervals for projected infection rates in 2017 from > 1,000 simulations.

$\dagger$ Proportion of the population still at risk for infection. 
bioRxiv preprint doi: https://doi.org/10.1101/187591; this version posted September 29,2017 . The copyright holder for this preprint (which was not certified by peer review) is the author/funder, who has granted bioRxiv a license to display the preprint in perpetuity. It is made available under aCC-BY-NC-ND 4.0 International license.

Preliminary modeling results for Zika virus transmission in 2017

September 12, 2017

Table 9: Probability of projected annual Zika virus infection rates $\geq 10 \%$ in 2017 for municipalities in the Americas

\begin{tabular}{|c|c|c|c|c|c|}
\hline Country & State & Municipality & $\begin{array}{c}\text { Municipality } \\
\text { population }\end{array}$ & $\begin{array}{c}\text { Model } 1 \\
\text { Probability of } \\
\text { infection rate } \geq 10 \% \\
\text { in } 2017\end{array}$ & $(95 \% \mathrm{Cl})$ \\
\hline Ecuador & Sucumbios & Lago Agrio/Nueva Loja & 249,959 & $49 \%$ & $(46-52)$ \\
\hline Peru & Tumbes & Tumbes & 283,424 & $48 \%$ & $(45-51)$ \\
\hline Peru & Piura & Piura & $1,730,114$ & $45 \%$ & $(43-48)$ \\
\hline Mexico & Sinaloa & Los Mochis & $1,049,654$ & $40 \%$ & $(38-43)$ \\
\hline Bolivia & Gran Chaco & Yacuiba & 243,077 & $27 \%$ & $(24-29)$ \\
\hline Ecuador & Orellana & El Coca & 151,629 & $21 \%$ & $(19-24)$ \\
\hline Paraguay & Alto Parana & Ciudad del Este & $2,336,625$ & $21 \%$ & $(19-23)$ \\
\hline Mexico & Tamaulipas & Tampico & $1,835,390$ & $18 \%$ & $(16-20)$ \\
\hline Honduras & Gracias a Dios & Puerto Lempira & 106,834 & $16 \%$ & $(14-18)$ \\
\hline Ecuador & Esmeraldas & Esmeraldas & 599,629 & $12 \%$ & $(10-14)$ \\
\hline Peru & San Martin & Tarapoto & $1,397,529$ & $10 \%$ & $(9-12)$ \\
\hline Colombia & Narino & Tumaco & 275,111 & $9 \%$ & $(7-10)$ \\
\hline Peru & Ucayali & Pucallpa & 694,810 & $8 \%$ & $(7-10)$ \\
\hline Mexico & Colima & Colima & 957,465 & $8 \%$ & $(6-9)$ \\
\hline Mexico & Baja California Sur & Cabo San Jose & 149,391 & $8 \%$ & $(6-9)$ \\
\hline Honduras & Colon & Guanaja/Tocoa & 221,233 & $6 \%$ & $(5-8)$ \\
\hline Colombia & Guainia & Puerto Inirida & 53,718 & $6 \%$ & $(5-8)$ \\
\hline Mexico & Michoacan & Lazaro Cardenas & 341,119 & $6 \%$ & $(4-7)$ \\
\hline Mexico & Sinaloa & Culiacan & $1,481,563$ & $5 \%$ & $(4-7)$ \\
\hline Colombia & Vichada & Puerto Carreno & 39,127 & $5 \%$ & $(4-6)$ \\
\hline Venezuela & Bolivar & Santa Elena & 8,160 & $5 \%$ & $(3-6)$ \\
\hline Mexico & Oaxaca & Santa Maria Huatulco & 665,936 & $4 \%$ & $(3-6)$ \\
\hline Mexico & Oaxaca & Puerto Escondido & 464,002 & $4 \%$ & $(3-5)$ \\
\hline Mexico & Colima & Manzanillo & 390,234 & $4 \%$ & $(3-5)$ \\
\hline Mexico & Chiapas & Tapachula & 921,029 & $3 \%$ & $(2-4)$ \\
\hline Mexico & Nayarit & Tepic & 934,532 & $3 \%$ & $(2-4)$ \\
\hline Mexico & Sinaloa & Mazatlan & 699,002 & $3 \%$ & $(2-4)$ \\
\hline Brazil & Parana & Umuarama & 518,546 & $3 \%$ & $(2-4)$ \\
\hline Mexico & Veracruz & Minatitlan & $1,881,784$ & $3 \%$ & $(2-4)$ \\
\hline Colombia & Amazonas & Tarapaca & 50,271 & $2 \%$ & $(2-3)$ \\
\hline
\end{tabular}


bioRxiv preprint doi: https://doi.org/10.1101/187591; this version posted September 29, 2017. The copyright holder for this preprint (which was not certified by peer review) is the author/funder, who has granted bioRxiv a license to display the preprint in perpetuity. It is made available under aCC-BY-NC-ND 4.0 International license.

Preliminary modeling results for Zika virus transmission in 2017

September 12, 2017

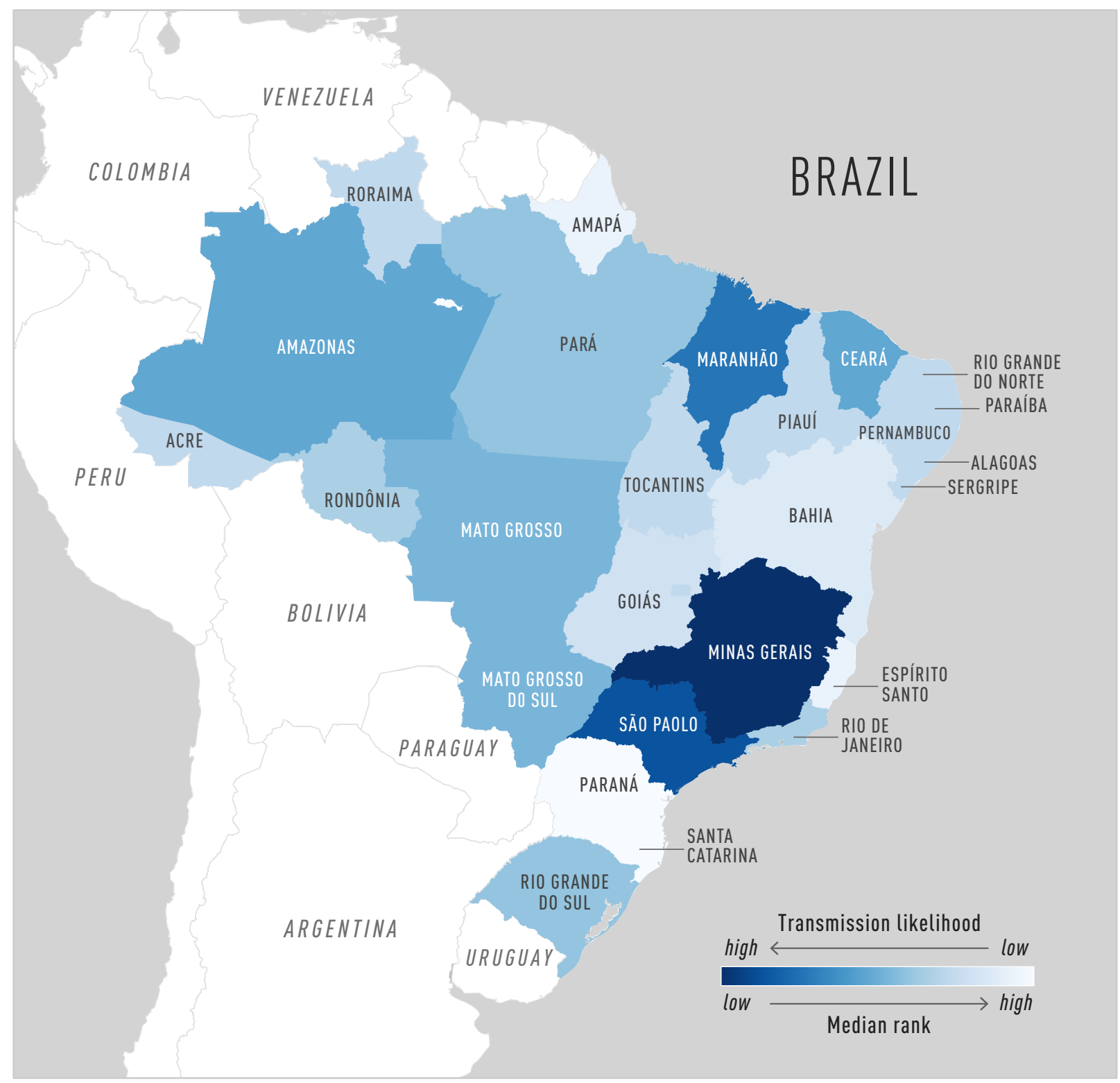

Figure 1: Median rank for the three models for each state in Brazil. The color scheme shows how each state ranks within the country. That is, the lower the rank (dark blue), the higher the relative likelihood of future Zika transmission. 
bioRxiv preprint doi: https://doi.org/10.1101/187591; this version posted September 29, 2017. The copyright holder for this preprint (which was not certified by peer review) is the author/funder, who has granted bioRxiv a license to display the preprint in perpetuity. It is made available under aCC-BY-NC-ND 4.0 International license.

Preliminary modeling results for Zika virus transmission in 2017

September 12, 2017

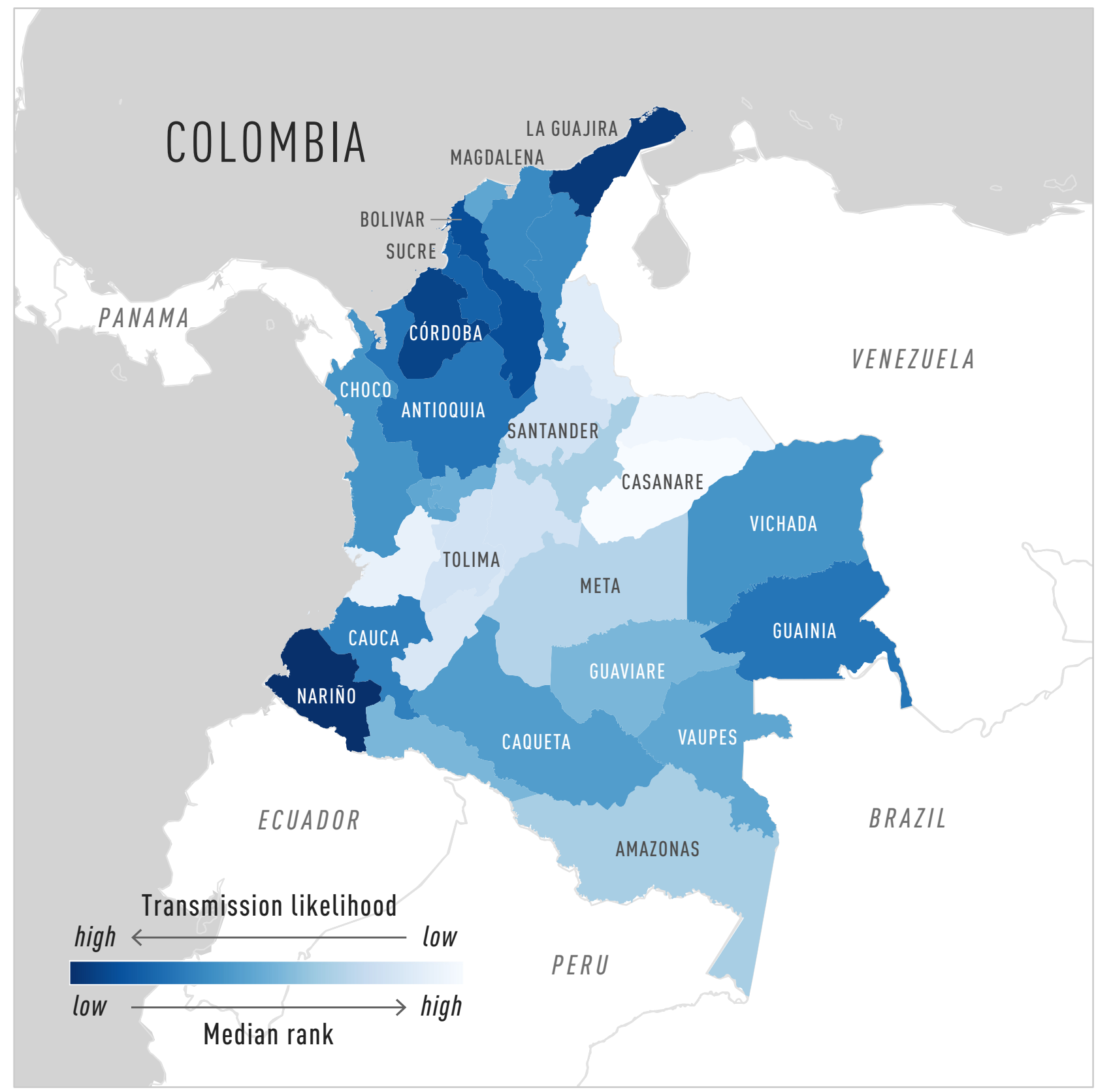

Figure 2: Median rank for the three models for each state in Colombia. The color scheme shows how each state ranks within the country. That is, the lower the rank (dark blue), the higher the relative likelihood of future Zika transmission. 
bioRxiv preprint doi: https://doi.org/10.1101/187591; this version posted September 29, 2017. The copyright holder for this preprint (which was not certified by peer review) is the author/funder, who has granted bioRxiv a license to display the preprint in perpetuity. It is made available under aCC-BY-NC-ND 4.0 International license.

Preliminary modeling results for Zika virus transmission in 2017

September 12, 2017

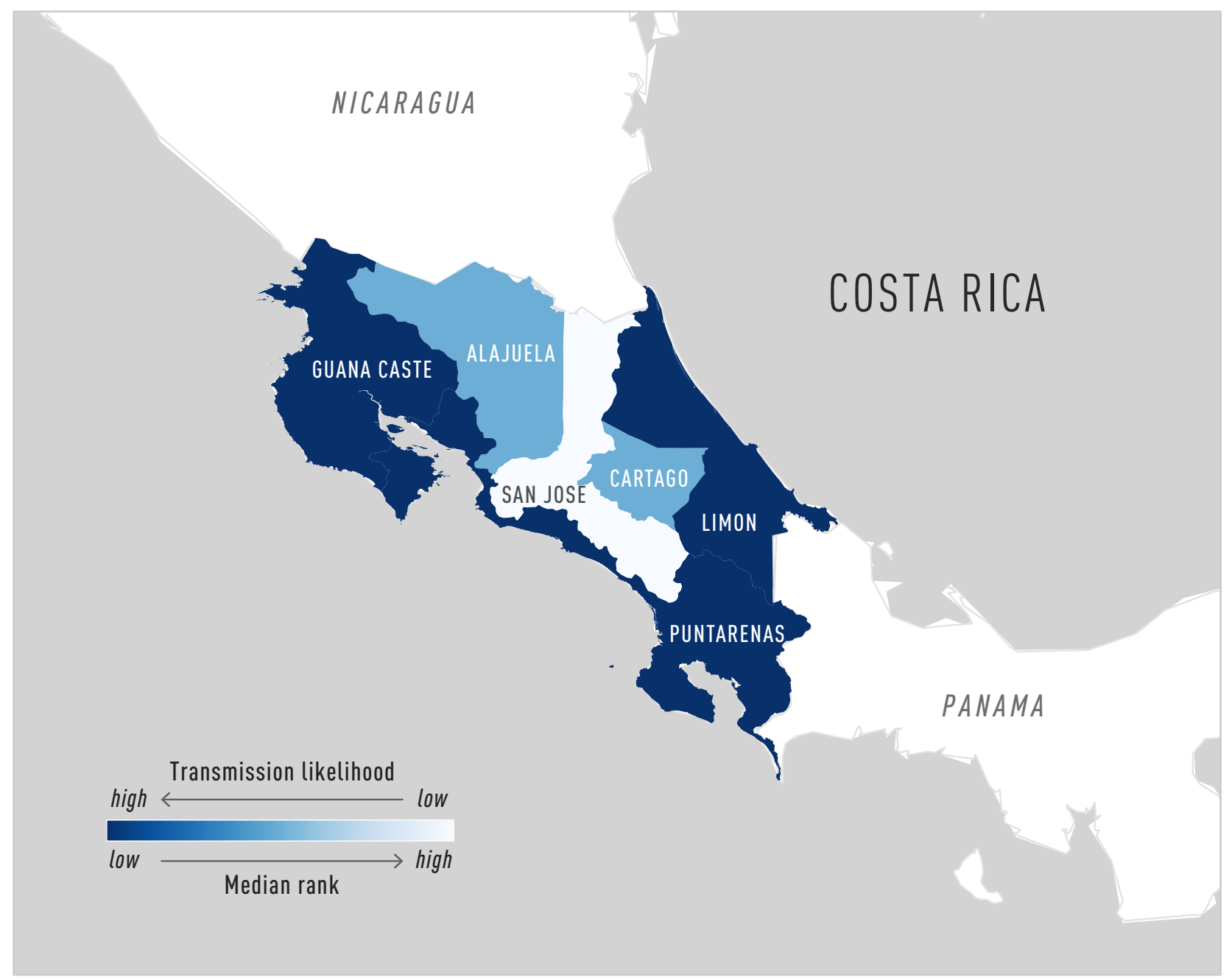

Figure 3: Median rank for the three models for each province in Costa Rica. The color scheme shows how each state ranks within the country. That is, the lower the rank (dark blue), the higher the relative likelihood of future Zika transmission. 
bioRxiv preprint doi: https://doi.org/10.1101/187591; this version posted September 29, 2017. The copyright holder for this preprint (which was not certified by peer review) is the author/funder, who has granted bioRxiv a license to display the preprint in perpetuity. It is made available under aCC-BY-NC-ND 4.0 International license.

Preliminary modeling results for Zika virus transmission in 2017

September 12, 2017

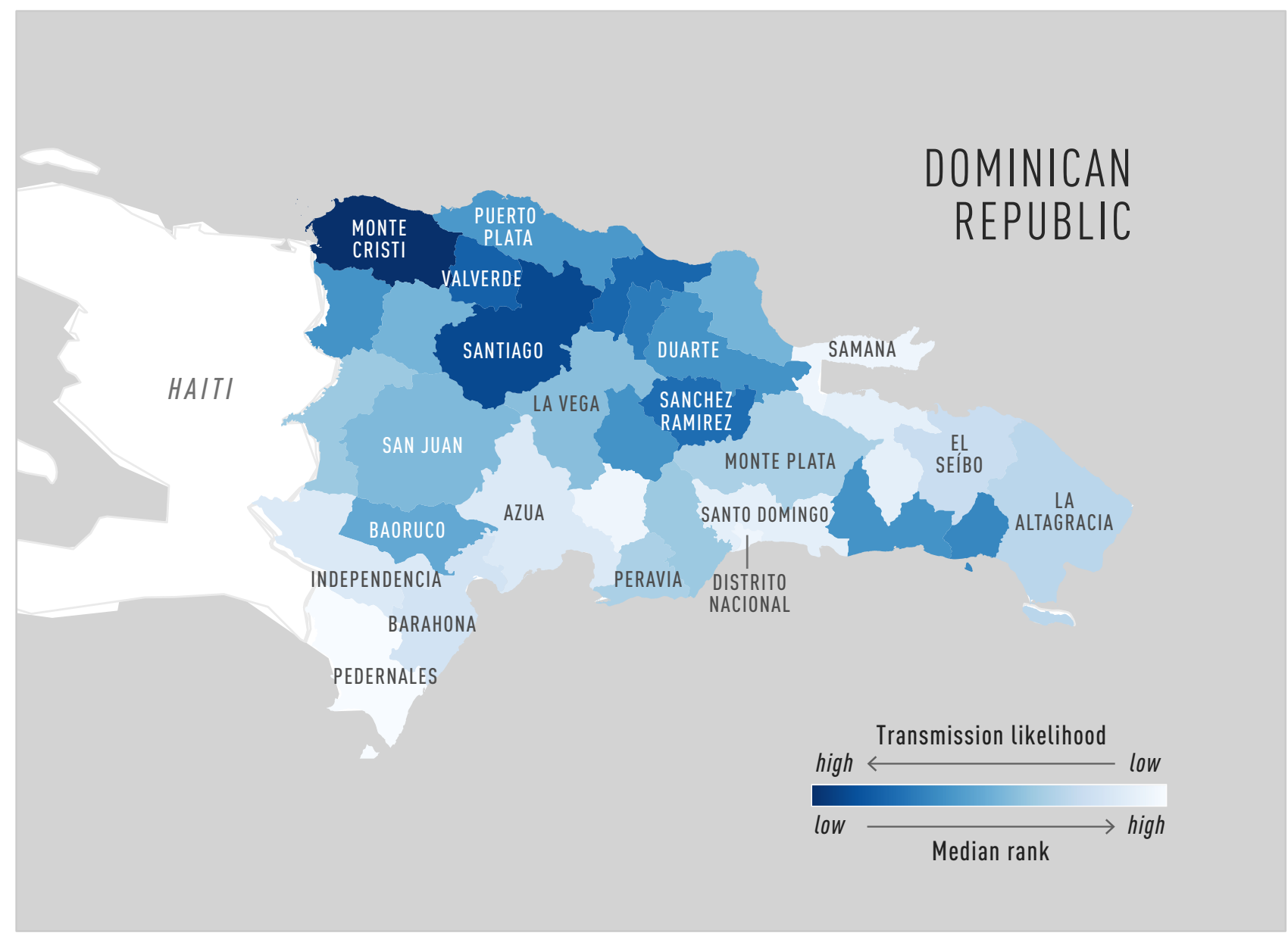

Figure 4: Median rank for the three models for each province in Dominican Republic. The color scheme shows how each state ranks within the country. That is, the lower the rank (dark blue), the higher the relative likelihood of future Zika transmission. 
bioRxiv preprint doi: https://doi.org/10.1101/187591; this version posted September 29, 2017. The copyright holder for this preprint (which was not certified by peer review) is the author/funder, who has granted bioRxiv a license to display the preprint in perpetuity. It is made available under aCC-BY-NC-ND 4.0 International license.

Preliminary modeling results for Zika virus transmission in 2017

September 12, 2017

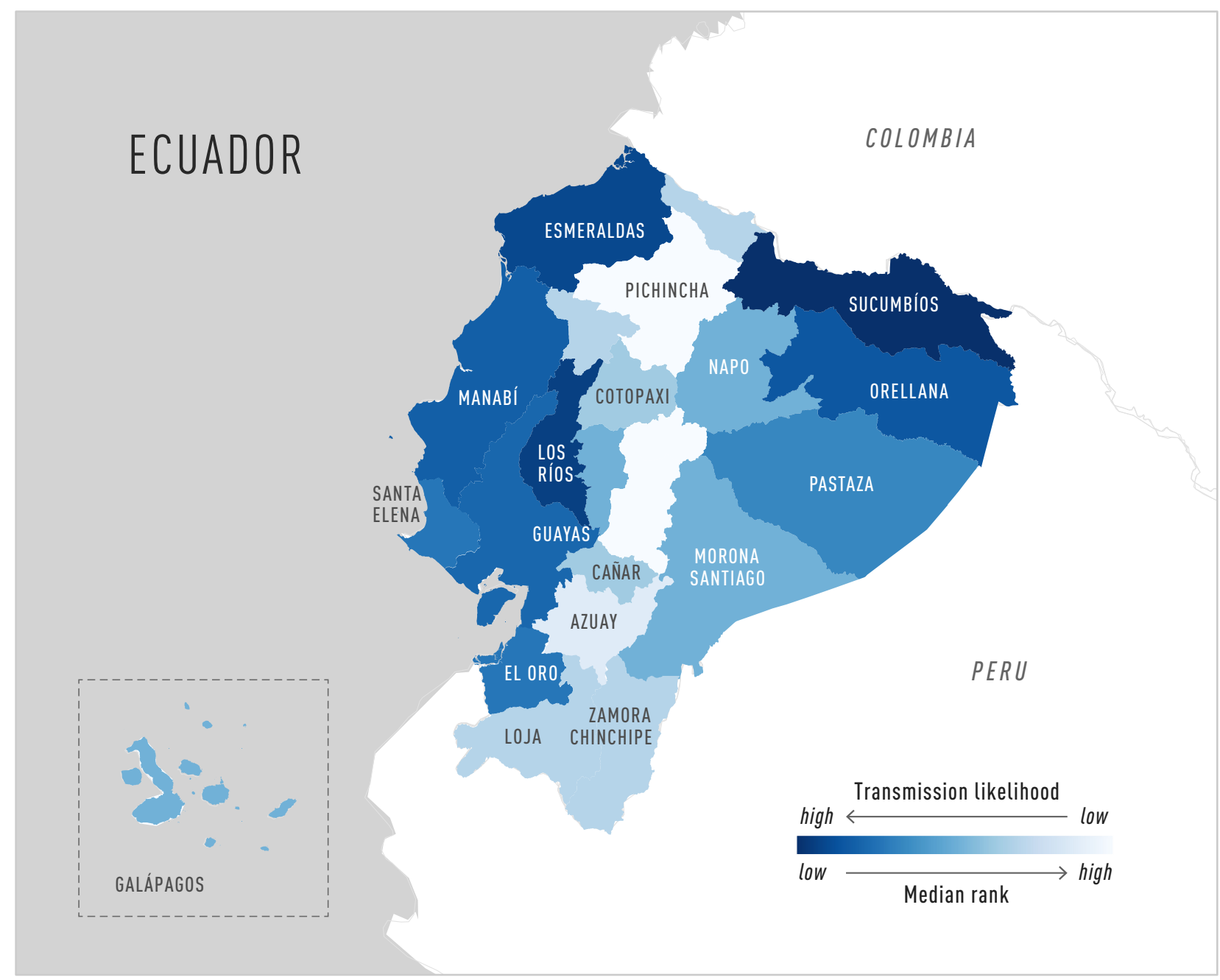

Figure 5: Median rank for the three models for each province in Ecuador. The color scheme shows how each state ranks within the country. That is, the lower the rank (dark blue), the higher the relative likelihood of future Zika transmission. 
bioRxiv preprint doi: https://doi.org/10.1101/187591; this version posted September 29, 2017. The copyright holder for this preprint (which was not certified by peer review) is the author/funder, who has granted bioRxiv a license to display the preprint in perpetuity. It is made available under aCC-BY-NC-ND 4.0 International license.

Preliminary modeling results for Zika virus transmission in 2017

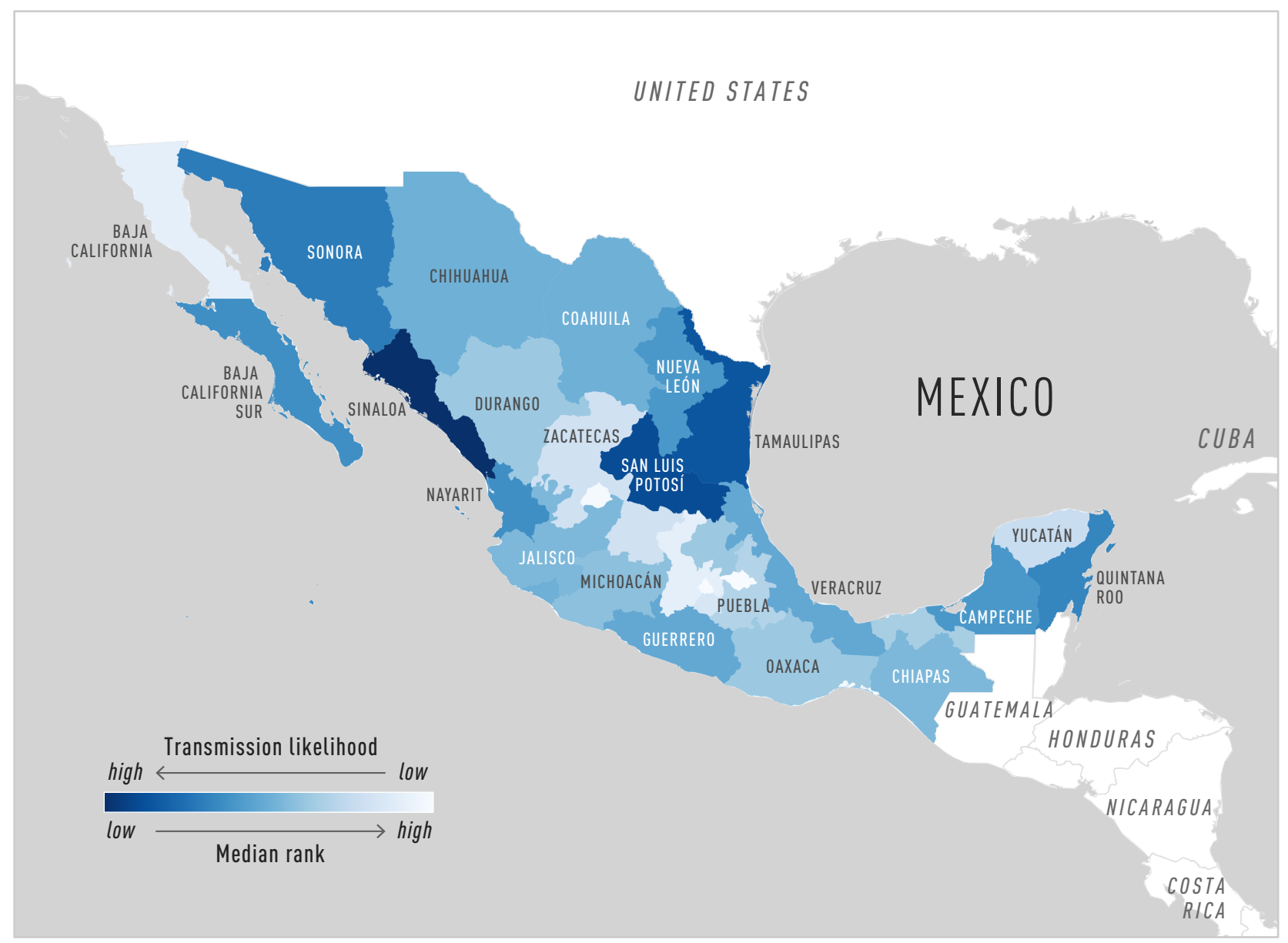

Figure 6: Median rank for the three models for each state in Mexico. The color scheme shows how each state ranks within the country. That is, the lower the rank (dark blue), the higher the relative likelihood of future Zika transmission. 
bioRxiv preprint doi: https://doi.org/10.1101/187591; this version posted September 29, 2017. The copyright holder for this preprint (which was not certified by peer review) is the author/funder, who has granted bioRxiv a license to display the preprint in perpetuity. It is made available under aCC-BY-NC-ND 4.0 International license.

Preliminary modeling results for Zika virus transmission in 2017

September 12, 2017

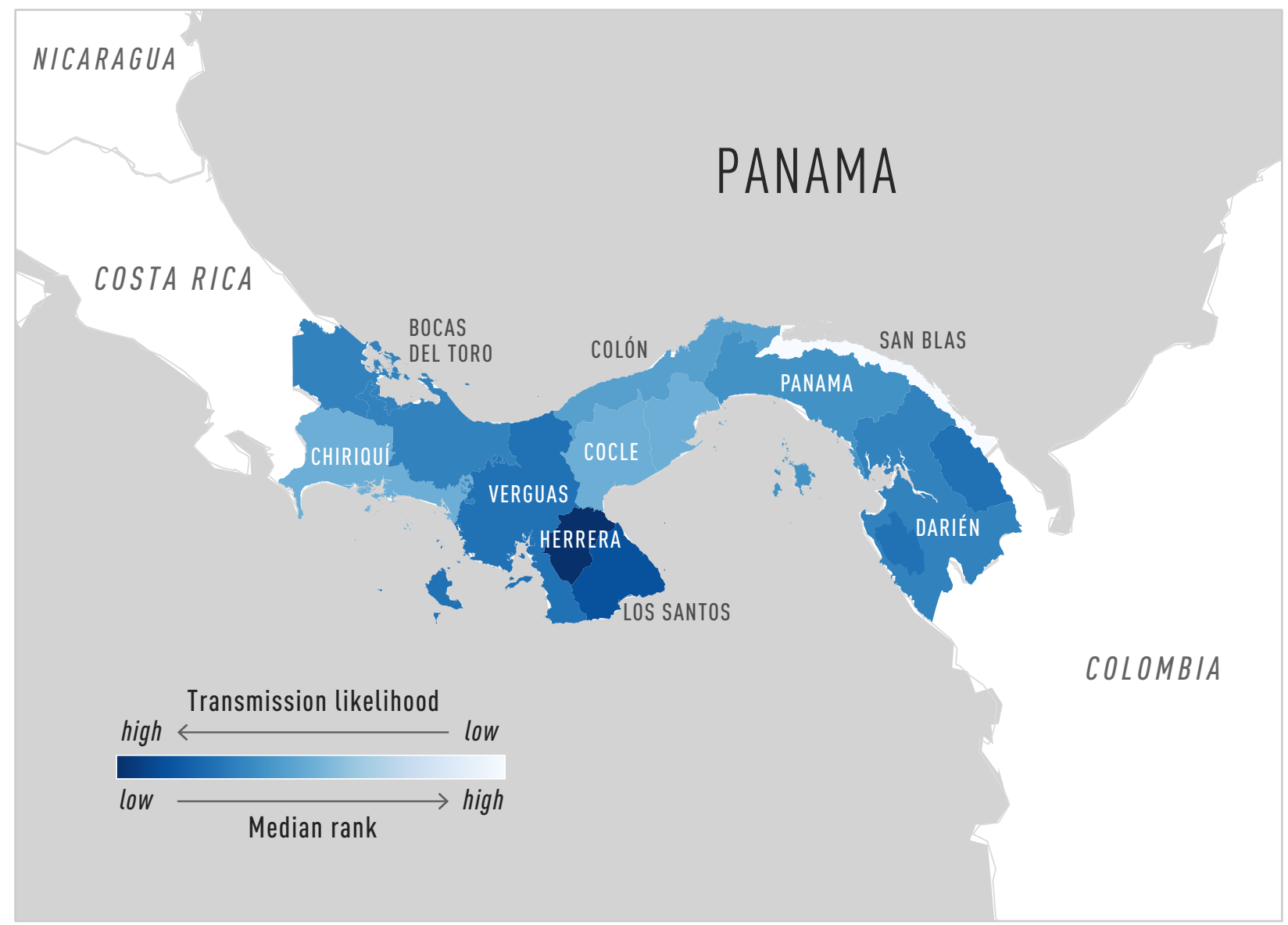

Figure 7: Median rank for the three models for each province in Panama. The color scheme shows how each state ranks within the country. That is, the lower the rank (dark blue), the higher the relative likelihood of future Zika transmission. 
bioRxiv preprint doi: https://doi.org/10.1101/187591; this version posted September 29, 2017. The copyright holder for this preprint (which was not certified by peer review) is the author/funder, who has granted bioRxiv a license to display the preprint in perpetuity. It is made available under aCC-BY-NC-ND 4.0 International license.

Preliminary modeling results for Zika virus transmission in 2017

September 12, 2017

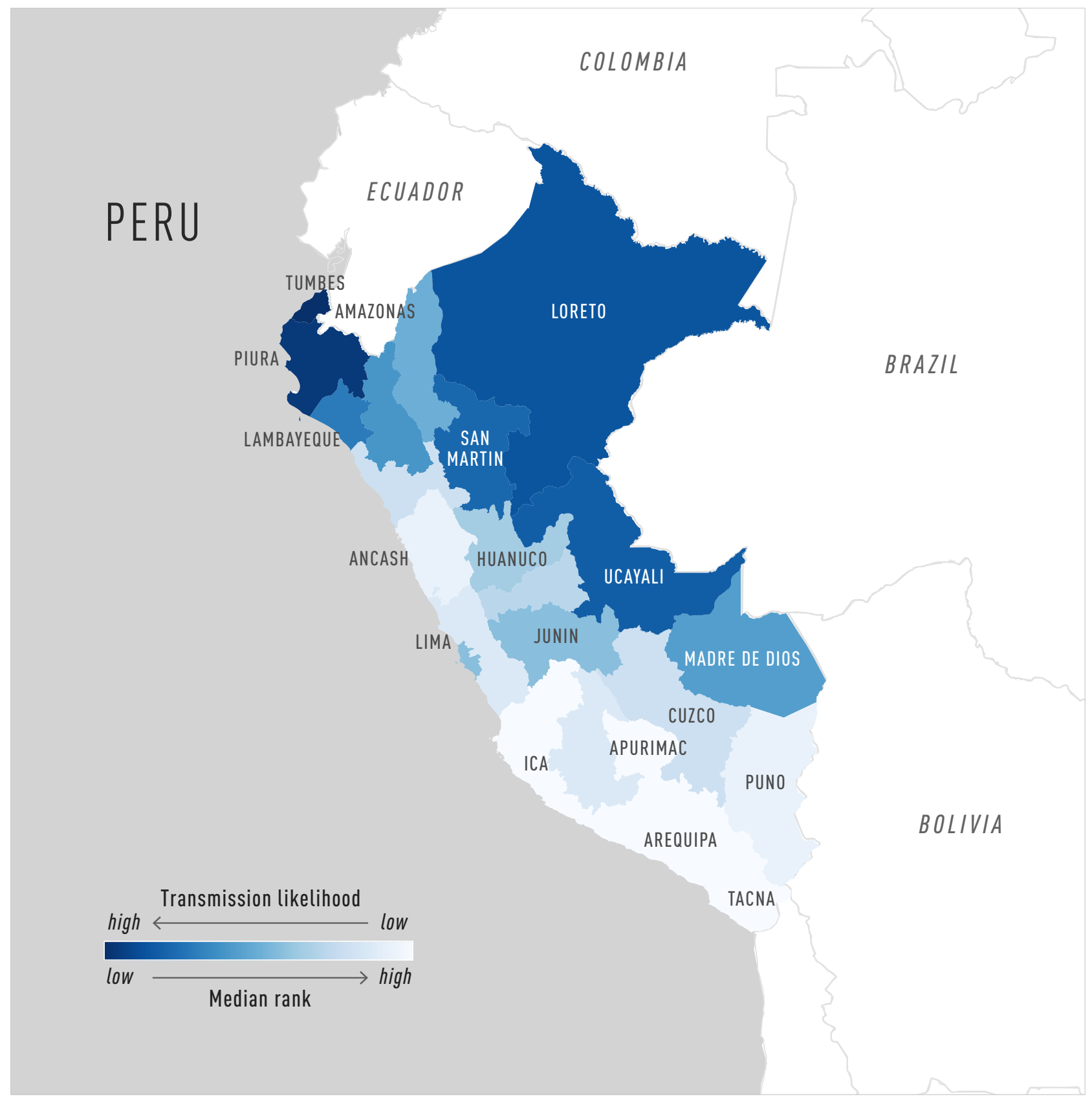

Figure 8: Median rank for the three models for each department in Peru. The color scheme shows how each state ranks within the country. That is, the lower the rank (dark blue), the higher the relative likelihood of future Zika transmission. 
bioRxiv preprint doi: https://doi.org/10.1101/187591; this version posted September 29, 2017. The copyright holder for this preprint (which was not certified by peer review) is the author/funder, who has granted bioRxiv a license to display the preprint in perpetuity. It is made available under aCC-BY-NC-ND 4.0 International license.

Preliminary modeling results for Zika virus transmission in 2017

September 12, 2017
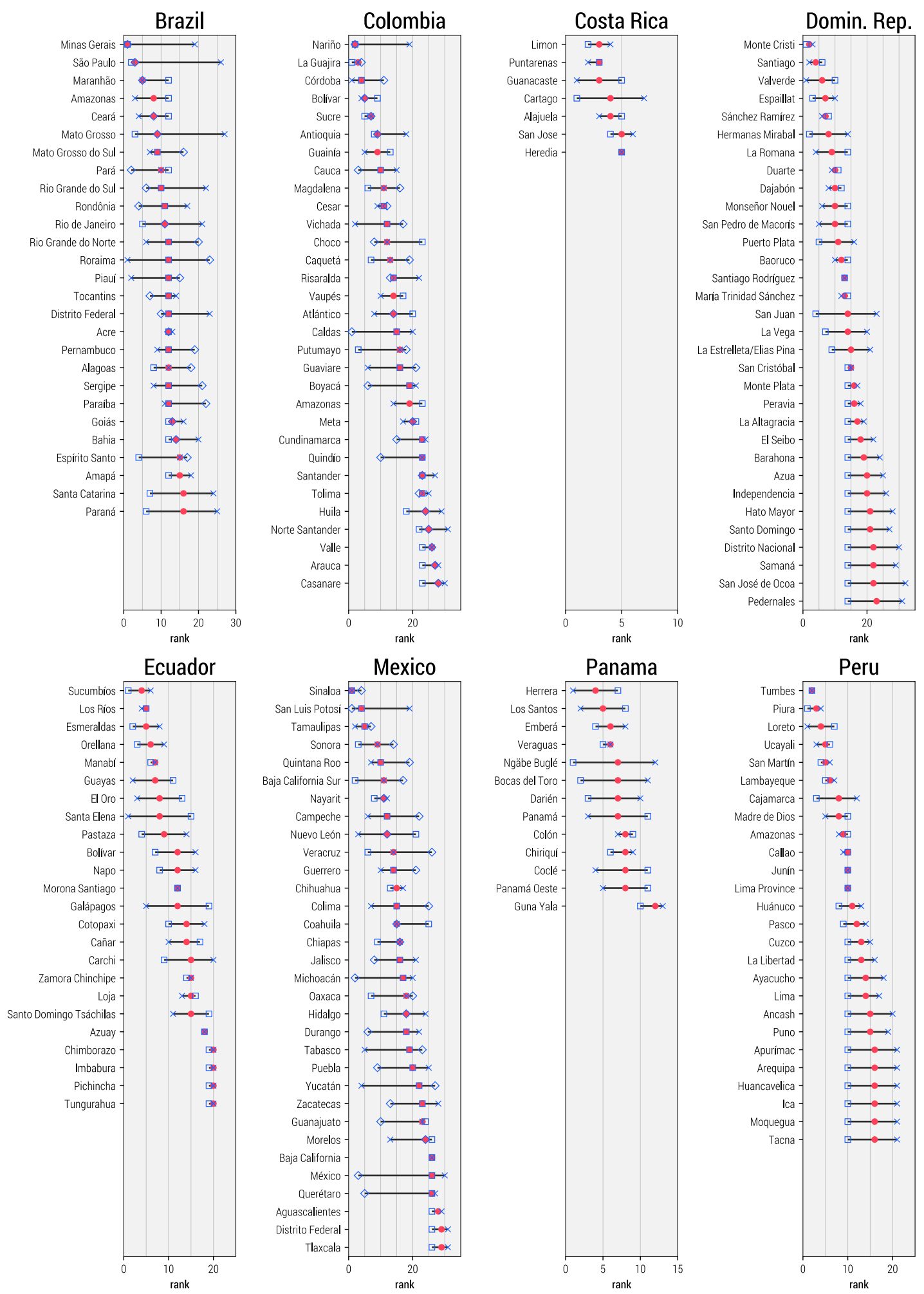

Figure 9: Median rank (red dot) and range of model ranks (black line) for each state/province within each country. Individual models are indicated by open blue shapes (square $=$ Model $1 ;$ cross $=$ Model 2; diamond $=$ Model 3). Additional details can be found in Tables 1-8. 